\title{
Floristic complexes on landslides of different age in Central Yamal, West Siberian Low Arctic, Russia
}

\author{
OLGA KHITUN, KSENIA ERMOKHINA, IRINA CZERNYADJEVA, MARINA LEIBMAN AND \\ ARTEM KHOMUTOV
}

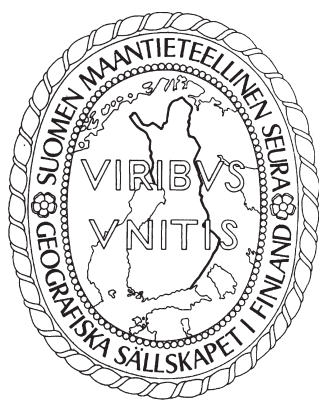

Khitun, Olga, Ksenia Ermokhina, Irina Czernyadjeva, Marina Leibman \& Artem Khomutov (2015). Floristic complexes on landslides of different age in Central Yamal, West Siberian Low Arctic, Russia. Fennia 193: 1, 31-52. ISSN 17985617.

Accurate ground-based datasets are important for correct interpretation of remote sensing data. West-Siberian Arctic has been exposed to rapid land-cover and land-use changes during the last 50 years. Cryogenic landslides are important disturbing agents in the region, especially in the central part of the Yamal Peninsula. Different succession stages in the recovery of cryogenic landslides are described at the example of 4 model ones formed respectively in 1989, in the middle of 1970s, in late 1950s or early 1960s and an ancient landslide back scarp dated with radiocarbon method as ca 1000 year old. Botanical survey was performed in 1991 and repeated in 2012, phytosociological study on the same landslides and their surroundings was performed in 1997-2002. Correlation between different syntaxa, age and morphological element of landslide is shown. Both projective cover and species composition change gradually on young and old landslides, though vegetation on the ancient ones did not change during the last 20 years. Pioneer communities on Yamal landslides are dominated by grasses (Deschampsia borealis, Puccinellia sibirica, Calamagrostis holmii, Poa alpigena ssp. colpodea, Dupontia fisheri). Proportion of various species differs both between years and different sections of the shear surface. Carex glareosa indicating saline deposits was recorded on landslides of all stages. Mosses play important role in the recovery and formation of organic horizon on the young landslides. Geochemical properties of the groundwater were analyzed and correlation of different communities with different levels of mineralization of groundwater is shown. Vegetation allows estimate the age of younger landslides and indicates the sites of possible ancient detachment.

Keywords: Yamal, cryogenic landslides, species composition, succession, mosses, groundwater

Olga Khitun \& Irina Czernyadjeva, Komarov Botanical Institute, Russian Academy of Sciences, Professor Popov street 2, 197376 St.-Petersburg, Russia, E-mails: khitun-olga@yandex.ru, irinamosses@yandex.ru

Ksenia Ermokhina, Marina Leibman \& Artem Khomutov, Earth Cryosphere Institute, Siberian Branch, Russian Academy of Sciences, Malygin street 86, 625000 Tyumen, Russia, E-mails: diankina@gmail.com, moleibman@mail.ru, akhomutov@gmail.com

\section{Introduction}

High-latitude ecosystems are increasingly exposed to rapid environmental changes (ACIA 2005). Remote-sensing data indicate productivity increases in various parts of the Arctic (Walker et al. 2009, 2012; Bhatt et al. 2010). For the correct interpreta- tion of satellite data, accurate ground-based vegetation surveys are necessary (Walker et al. 2012). Recently, much attention has been given to the study of land-use and land-cover changes in the West Siberian Arctic, particularly on the Yamal Peninsula following gas industry development as well as traditional land-use (Walker et al. 2012; 
see also references in Kumpula et al. 2011, 2012). Another field of intensive research in the same region is the study of cryogenic landslides which attracted increased attention after hundreds of slope failures took place over several days in August 1989 (see review paper by Leibman et al. 2015). Floristic and geobotanical studies of the 1989 and previous failures were undertaken (Rebristaya et al. 1995; Ukraintseva, 1997, 1998; Ukraintseva et al. 2000, 2003; Yermokhina \& Myalo 2012).

Due to the presence of tabular ground ice at depths of 1 to $25 \mathrm{~m}$, different types of cryogenic landslides (see the review paper by Leibman et al. 2015 for more information regarding landslide terminology, mechanisms and classification) are common in the central part of the Yamal Peninsula (Leibman 1995; Leibman \& Kizyakov 2007). In contrast to flow-type failures, rapid movement of relatively rigid and dry active layer that occurs in summer on permafrost slopes are generally called "active layer detachment slides" (Lewkowicz 1990; Harris \& Lewkowicz 1993). In Russia, a detailed classification of cryogenic landslides is published by Leibman and Kizyakov (2007) and the type under consideration is called "cryogenic translational slide". This is further sub-categorized according to the composition of active layer sediments (sand or clay). However, the main focus of the paper is vegetation, and therefore international readers may be more familiar with the terms "active layer detachment slide" or simply 'landslide'; they will be used henceforth when referring to the cryogenic translational slide.

Active layer detachment slides have been described also in the Mackenzie Valley (Mackay \& Mathews 1973), Yukon (Lipovsky et al. 2006) and in Canadian High Arctic (Edlund et al. 1989; Lewkowicz 1990; Harris \& Lewkowicz 1993). Unusually warm late summer temperatures along with heavy rainfalls were reported as the most important trigger factors leading to detachments (Edlund et al. 1989; Lewkowicz 1990; Leibman 1995). These cause rapid thawing of ice-rich deposits at the active layer base, which due to low filtration rates in fine-grained sediments led to the accumulation of excess water in the active layer and a critical increase in porewater pressure (Lewkowicz 1990; Harris \& Lewkowicz 1993; Leibman et al. 1993; Leibman \& Egorov 1996). The gravity causes rapid sliding of the active layer coherent mass over a basal shear zone. Desiccation caused by evaporation and two-sided freezing is thought to be the reason for such coherence (Harris \& Lewkowicz 1993; Leibman 1995; Leibman \& Kizyakov 2007).
In general, active layer detachment slides result in the formation of bare mineral scar zones called shear surfaces and depositional areas, where an earth mass shifts with vegetation. The latter is called a landslide body, which usually consists of several detached blocks (Harris \& Lewkowicz 1993; Leibman \& Kizyakov 2007). Landslides alter both topography and soil, which also creates new habitats for colonization (Geertsema \& Pojar 2007; Cannone et al. 2010).

Arctic ecosystems are extremely vulnerable and long timeframes are required for recovery after either natural or anthropogenic disturbances. Due to the severity of the climate, only local flora species were shown to participate in recovery (Walker et al.1987; Matveeva 1989; Walker \& Walker 1991; Khitun 1997; Sumina 2013). The rates of recovery vary in Low and High Arctic regions and depend on the size of disturbance and availability of propagules (Walker \& Walker 1991).

Vegetation on exposed mineral ground differs markedly from adjacent undisturbed tundra both in the terms of species composition, total coverage of vegetation and coverage of different species and plant functional types (Walker \& Walker 1991; Rebristaya et al. 1995; Cannone et al. 2010). Pioneer species using a ruderal strategy (Grime 1979) are the first to colonize the barren ground, however, the species composition found in various parts of the Arctic differs (cf. Walker et al. 1987; Forbes 1994; Jorgenson 1997; Khitun 1997; Cannone et al. 2010; Sumina 2013).

Classification of tundra communities is fraught with difficulties as many species have a wide ecological amplitude and there is considerable floristic overlap between many widespread communities (Muc et al. 1989; Matveeva 2006); this is especially true for communities re-vegetating disturbances (Sumina 2013). The Braun-Blanquet (1964) approach, which considers the complete species composition (vascular plants, bryophytes, lichens), is gaining acceptance by many botanists and has been suggested as the approach for the Arctic Vegetation Archive (Walker 2013).

In the Low Arctic, increased frequency in disturbance regimes may influence the effect of warming temperature on vegetation (Lantz et al. 2009). Data from the West Siberian Arctic indirectly support this idea. The presence of willow thickets which were unusually tall for that latitude (up to $150 \mathrm{~cm}$ ) was recorded on concave slopes in Central Yamal (Rebristaya et al. 1995; Ukraintseva 1998) and is thought to be connected with repeti- 
tive slope failures in the past (Ukraintseva et al. 2000, 2003). Previously buried landslide body soil and vegetation remnants were found on such slopes, in some cases even twice, and were dated between 330-2200 years old (Leibman \& Kizyakov 2007; Leibman et al. 2015). Desalinization of old marine sediments exposed by landslides led to the water-soluble salt enrichment of the active layer, providing better mineral supply for plants colonizing the shear surface (Ukraintseva et al. 2000, 2003). When willows (Salix glauca, S. lanata) start to colonize the shear surface, they, in turn, enrich this layer with nitrogen and organic matter. It is suggested that deeper snow within concavities could be an additional factor enabling taller growth (Leibman 2004). Similar observations, however, concerning the recovery of retrogressive thaw slumps, were reported recently from Alaska where a shift from graminoid-dominated to tall shrub-dominated communities was recorded 3060 years after disturbance (Pizano et al. 2014)

Geochemical consequences of active layer detachment slides in Central Yamal were studied in detail (Tentyukov 1998; Ukraintseva et al. 2000, 2003; Leibman \& Kizyakov 2007; Leibman et al. 2015). Vertical migration and horizontal leaching of readily soluble salts were observed due to the thawing of previously frozen deposits which had been exposed after a landslide event. When saline frozen deposits (with $\mathrm{Na}^{+}$and $\mathrm{Cl}^{-}$ions predominating due to the marine origin) start to melt, demineralization starts as well and groundwater at the active layer base is increasingly characterized by high salt content. Whereas groundwater in the active layer on stable slopes has low salt concentrations $(0.05-0.1 \mathrm{~g} / \mathrm{l})$, on young shear surfaces salt concentration increases sharply $(1-2 \mathrm{~g} / \mathrm{l})$, while on ancient shear surfaces it decreases to $0.4-0.8 \mathrm{~g} / \mathrm{l}$ but still remains higher than background observations (Ukraintseva et al. 2003).

The aim of this paper is firstly to reveal the species composition and general patterns of recovery on active layer detachment slides of different ages in the Yamal region. Secondly, we indicate species and communities typical for the different stages of recovery or distinct morphological elements of landslides. Thirdly, we suggest a preliminary classification of communities on landslide-affected slopes; and finally, we investigate the correlation between geochemical properties (in particular salt content in groundwater) and the occurrence of certain plant communities.

\section{Study area}

The study was conducted at the Vaskiny Dachi research station which is located in Central Yamal $\left(70^{\circ} 20^{\prime} \mathrm{N}, 68^{\circ} 51^{\prime} \mathrm{E}\right)$ on the watershed of Seyakha and Mordyyakha Rivers, in the vicinity of the Ngaranato Lake (Fig. 1). According to the botanicalgeographical regionalization (Yurtsev 1994), the area belongs to the subzone of northern hypoarctic tundra. According to the Circumpolar Arctic Vegetation Map, it is classified as bioclimatic subzone D (CAVM Team 2003).

The closest climate station is Marresale which is located on the coast, ca $100 \mathrm{~km}$ south west of Vaskiny Dachi. For the last 10 years the average January temperature at Marresale was $-21.5^{\circ} \mathrm{C}$, in July it was $7.5^{\circ} \mathrm{C}$, and mean annual air temperature was $-7.5{ }^{\circ} \mathrm{C}$ (www.rp5.ru). Total precipitation is ca 300 $\mathrm{mm}$, half of which falls as snow. Snow depth on the hill-tops is 5 to $30 \mathrm{~cm}$, but in topographical depressions, such as gullies, it can reach several metres.

The local physiography consists of gently undulated lacustrine-fluvial-marine plains and terraces at elevations between 18-55 m above sea level intersected by numerous creek and river valleys and gullies. Most of the area consists of gentle slopes (with angles less than $7^{\circ}$ ), with steep slopes occupying only $10 \%$ of the area. Additionally, flat hilltops and depression bottoms make up about 30\% of the area. Surficial materials on the plains are sandy to clay-rich underlain by saline clays. The geology of the region is described in detail in Leibman et al. (2015). The entire Yamal Peninsula lies within the zone of continuous permafrost which extends up to $500 \mathrm{~m}$ (Yershov 1998); active layer depth varies from $40 \mathrm{~cm}$ under dense moss cover to $120 \mathrm{~cm}$ on eroded sands (Leibman et al. 2012). Cryogenic processes (landslides, thermo-erosion) in the region are connected with the presence of tabular ground ice, however, modern thermokarst is less common (Leibman \& Kizyakov 2007). It was estimated that up to $70 \%$ of the territory has been affected by ancient landslides (Ukraintseva et al. 2003) which is the reason for the abundance of tall willow shrubs on the slopes.

Loamy moderately drained hill tops and their gentle slopes are occupied by hummocky low shrub-sedge-moss communities (with Salix glauca, Betula nana ca $20-30 \mathrm{~cm}$ high, Salix polaris and Vaccinium vitis-idaea, Carex actisibirica, Hylocomium splendens, Aulacomnium turgidum, Dicranum elongatum, Polytrichum juniperinum). Such communities are assumed as zonal vegetation (Re- 
a

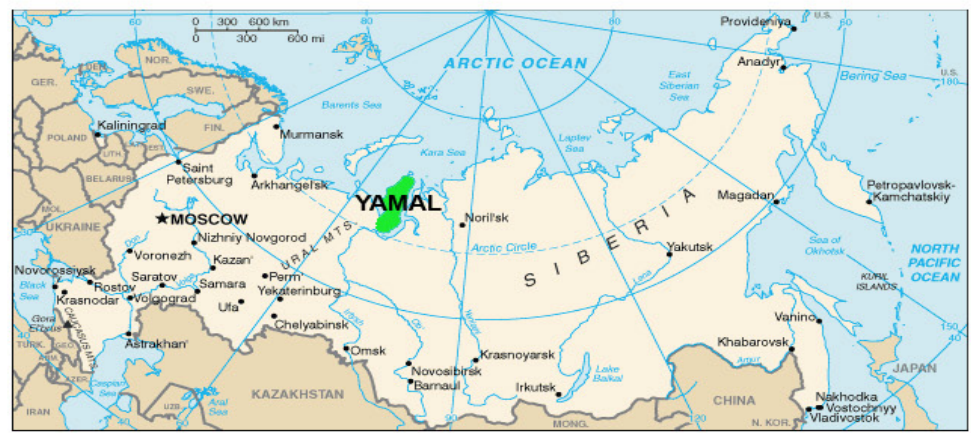

b
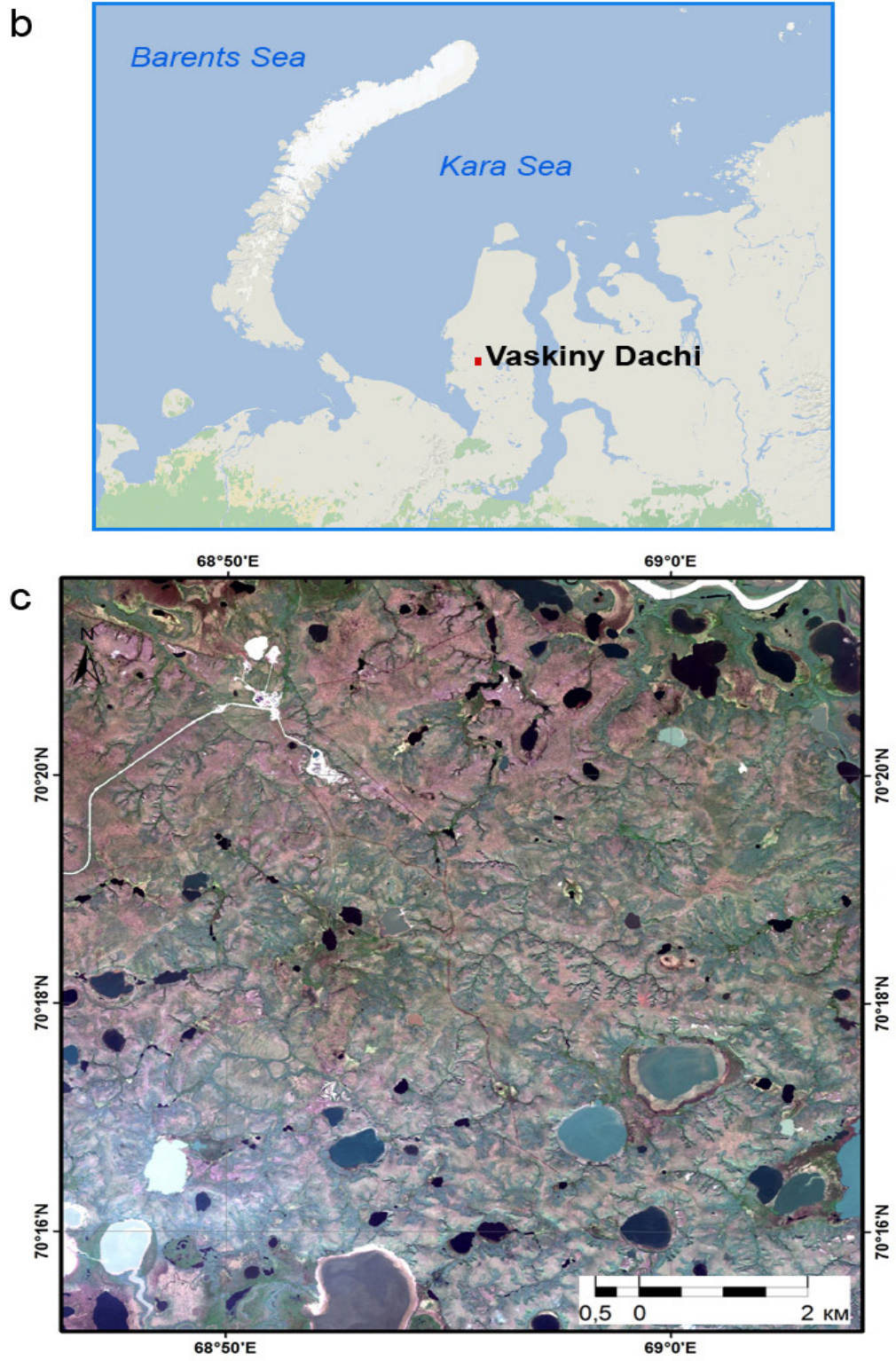

Fig. 1. Locations of Yamal Peninsula in Russian Arctic (a) and Vaskiny Dachi research station in Yamal (b) and a satellite image (GeoEye, 15-08-2009, resolution $0.5 \mathrm{~m}$ ) of the surroundings of the station (c). 
bristaya \& Khitun 1998). Sectors of the watershed hills with poor drainage are occupied by Salix glauca-Eriophorum polystachion dominated communities with sparse moss cover. Well-drained sandy edges of creek valleys and lake depressions with non-sorted polygons caused by frost cracking have sparse vascular plant cover with Betula nana, Dyas octopetala, Salix nummularia, Vaccinium vitis-idaea sprawling in the cracks and crustose lichens and liverwort Gymnomitrion corallioides abundant on tops of the polygons. There were 156 vascular plant species (Rebristaya \& Khitun 1998) and 127 mosses (Czernyadjeva 1995) observed within the area of ca $100 \mathrm{~km}^{2}$ around Vaskiny Dachi.

\section{Materials and methods}

\section{Categorization of landslides}

Different successional stages in the recovery of active layer detachment slides were described on four landslides which occurred respectively in 1989 (observed directly); in the late 1970s; in the late 1950s or early 1960 s (estimated with the help of available aerial photographs and climate data) and approximately 1000 years old (estimated by radiocarbon dating). Additional information about the possible date of landslide occurrences can be obtained by dendrochronological investigations, as annual ring width decreases sharply after sliding in spite of favorable temperature conditions (Gorlanova 2002). Landslides were subjectively categorized into 'young,' 'old,' and 'ancient.'
Young (0 - ca 30-50 years) landslides can be easily noticed by their bare surface in the first years, and are later covered with sparse pioneer groupings without continuous moss cover. They can be subdivided respectively into 'fresh' - practically lacking vegetation, and 'stabilized' - covered by grass groupings. Young landslides exhibit all the characteristic of active layer detachment slides with regard to morphological elements: back scarp, lateral berms, shear surface, blocks of landslide body and front-end scarp (Fig. 2). In the first 3-5 years after failure, the shear surface is very unstable, practically lacking vegetation, erosion is rapidly ongoing, icy layers ablate, small narrow troughs or rills form, indicating run-off.

Old (approximately between 35-50 to 150-200 years old) landslides also have all the above-mentioned morphological elements but less distinct as their surfaces have been washing out and getting increasingly smooth; deep troughs produced by run-off become wider and shallower and usually are the first to be completely re-vegetated by sedge dominated communities. More convex parts usually still have grass-dominated communities, thin but more or less continuous moss cover has been formed and willows have been regenerating actively on the entire landslide surface.

Amphitheater-shaped concave slopes completely covered by willow shrub thickets of various densities and well-developed moss cover were recognized as formed by series of ancient landslides which were dated between 300 to 2200 years old, and were referred to as "landslide cirques". The radiocarbon dating of buried soil horizons was performed in the isotope geochemistry and geochro-

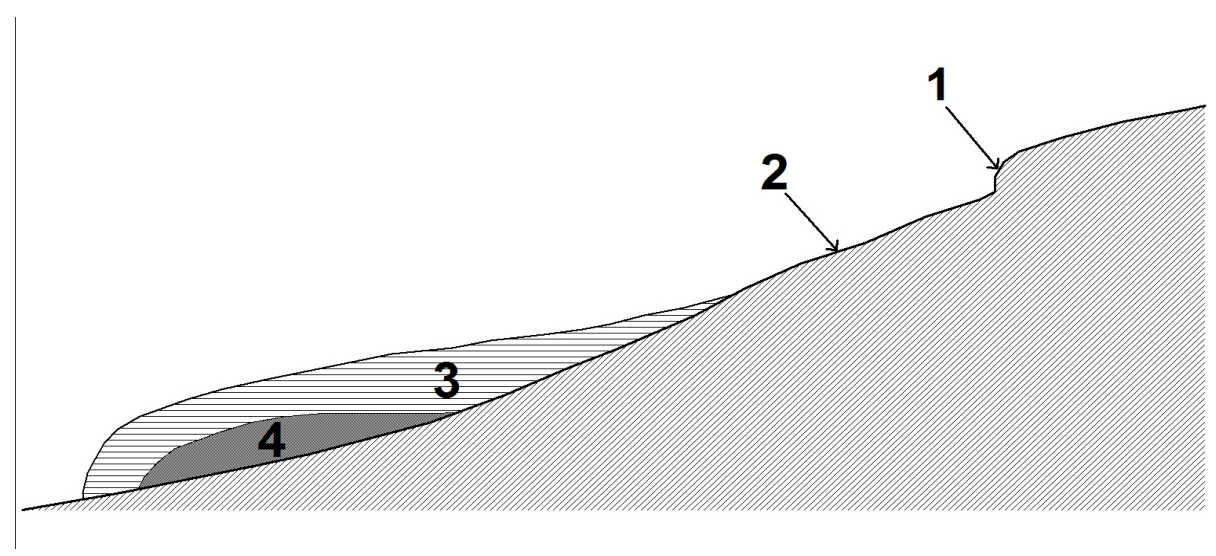

Fig. 2. Cross-sectional schematic drawing of the main morphological elements of the landslide: 1 - scarp, 2 - shear surface, 3 - landslide body and 4 - buried organic matter. 
nology laboratory of the Geological Institute of the Russian Academy of Sciences, Moscow (see more detail in Leibman et al. 2015) and is accurate within a range of \pm 40 to \pm 180 years. For the 1000 -year-old landslide under investigation, the accuracy was \pm 60 years. Buried organic matter was found at depths 60 to $80 \mathrm{~cm}$. It is probable that this stage can be achieved already after 150-200 years but among the sampled surfaces the youngest was 300 years old. Usually such slopes are more concave and moist in the upper part (former shear surface) and better drained in the lower part (former landslide body).

\section{Methods of vegetation study}

Species composition was studied via thorough survey on each landslide in 1991-1993, vouchers were collected for all species and field determinations were verified in the lab where necessary. Species lists were compiled separately for shear surface, landslide body and undisturbed communities adjacent to the detachment slide. Sketch maps were drawn to show the location of different groupings on the landslide surface and variations in microtopography. An identical survey was repeated in 2012.

Vegetation was described in $5 \times 5 \mathrm{~m}$ sample plots in undisturbed communities as recommended (Korchagin et al. 1964; Matveeva 2006), and in $2 \times 2 \mathrm{~m}$ plots on landslides; sample plots were set up at the sections of the landslide which visually (by dominating species) differ from neighboring sections. Additionally between 1997-2002, for the purpose of classification 165 relevés were made along several transects starting at the stable surface, crossing the shear surface, the landslide body, the front wall and ending at the undisturbed foot slope at $10 \mathrm{~m}$ intervals. Total vegetation coverage as well as the cover for each of the vascular plant species and mosses were estimated as a percentage of the total plot area as observed projection from above (referred from now on as projective cover, PC). Total PC cannot exceed $100 \%$ in contrast to the sum of PCs of different species or plant functional types as their projections can overlap each other. PC was estimated visually during floristic surveys and using a Ramensky's frame $(100 \times 100 \mathrm{~cm}$ frame divided into 100 cells) during the phytosociological study. For all plots, the following site characteristics were recorded: microand nanorelief; site moisture (subjectively: dry or wet); the presence and thickness of organic soil horizon; the number of vegetation layers and height of each; total PC and PC of various species and plant functional types (shrubs, dwarf-shrubs, grasses, sedges, herbs, green mosses, lichens).

For individual species both percentage cover and scalar estimates were used as the latter are commonly used in synoptic tables (Aleksandrova 1969; Matveeva 2006). Synoptic constancy tables were sorted manually by the tabular method (Aleksandrova 1969) in Excel 2007. The Braun-Blanquet (1964) approach to classification was used as it allows the differentiation of a relatively limited number of syntaxa and reveals their correlation with habitat's specific and successional position compared to the dominant classification (Sukachev 1934) which is more common in Russia and which was used for the overall description of vegetation. In diagnostic tables, the species constancy classes correspond to their occurrence in certain groups of relevés: I) $1-20 \%$, II) $21-40 \%$, III) $41-60 \%$, IV) $61-80 \%$, and V) $81-100 \%$. Species with constancies IV-V in certain groups of relevés were considered as differential species for this group. Classification using the Braun-Blanquet method requires further elaboration for tundra vegetation (Matveeva 2006). Classification of pioneer vegetation causes many difficulties (Sumina 2013). This matter needs more detailed study and therefore only preliminary prodromus is suggested. The rank and names of distinguished units are preliminary and will be revised after further research. But for this study, it was important that different vegetation units were indicating differences in abiotic conditions, particularly in soil geochemistry in the diverse sections of landslides and especially on landslides of different age. Distinguished syntaxa were described according to the International Code of Phytosociological Nomenclature (Weber et al. 2000). In total, two new alliances, seven associations, 23 sub-associations and four variants were suggested for the surroundings of Vaskiny Dachi (Ermokhina 2009). Some of them will be considered in this paper (Table 1). Alliance Equiseto-Salicion glaucae most probably should be included in one class with the alliances of orders Phippsio-Cochleariopsietalia Hadač 1989 and Chamerio-Betuletalia nanae Khusainov et al. 1989 ord.prov. (including Matricario-Poetalia alpigenae Ishbirdin 1991 prov.), which join communities of naturally or anthropogenically disturbed habitats in the Russian North. But this class is not yet determined in the literature (Mirkin \& Naumova 1998). Alliance Equiseto-Salicion glaucae includes some diagnostic species of class Salici-Betuletea nanae Khusainov in Khusainov et al. 1989, describing dwarf-shrub lichen and moss tundra. 
Taxonomy follows Sekretareva (1999) for vascular plants, Ignatov et al. (2006) for mosses and Andreev et al. (1996) for lichens.

\section{Geochemical study}

Soil and groundwater samples (721 and 317 samples, respectively) were collected according to standard methods (Kovalskii \& Gololobov 1969) from the core of shallow boreholes in dry sites usually at a depth of $10-30 \mathrm{~cm}$ for soil samples and 50-80 cm for groundwater. In wet sites, samples for groundwater were taken at $20-40 \mathrm{~cm}$. Ionic composition was tested to analyze the redistribution of water-soluble salts in the newly formed active layer. The laboratory analysis of soil samples and groundwater was performed in the Vernadsky Institute of Geochemistry and Analytical Chemistry Russian Academy of Sciences according to standard methods (Tkachev \& Yudovich 1975). It included the determination of soil moisture, $\mathrm{pH}$, exchangeable cations and anions, and ion composition of supra-permafrost groundwater. More details on geochemical research are given in Leibman et al. in this volume.

For different morphological elements of the landslides of different age categories, the sums of salts and content $(\mathrm{g} / \mathrm{l})$ of $\mathrm{Cl}^{-}, \mathrm{Ca}^{2+}, \mathrm{Mg}^{2+}, \mathrm{SO}_{4}{ }^{2-}, \mathrm{K}^{+}$, and $\mathrm{P}_{2} \mathrm{O}_{5}$ in supra-permafrost groundwater were calculated. Measured values followed log-normal distribution. Confidence intervals for the content of each ion for various plant communities and for different morphological elements of the landslide were calculated according to recommendations given in textbooks on phytoindication (Vinogradov 1964; Viktorov \& Remezova 1988), with a 70\% threshold (i.e. $70 \%$ of measured values are within this interval).

Canonical correspondence analysis (Gauch 1982) was performed in the program BioDiversity Pro, with matrices including data on species constancies in all distinguished syntaxa (a complete list of species) and environmental data including salt content in groundwater.

\section{Description of the studied landslides}

Pattern of re-vegetation was similar on all fresh young landslides which detached in 1989, therefore just one of them was chosen as representative for this study, henceforth referred to as L1. L1 is on approximately $3^{\circ}$ steep, northeast-facing slope of lake depression. The range of its movement was $180 \mathrm{~m}$, including a $120 \mathrm{~m}$ shear surface, with a width of $50 \mathrm{~m}$. The landslide occurred in an asym- metrical run-off depression, with almost $1.5 \mathrm{~m}$ high scarp on the left side and about $60 \mathrm{~cm}$ high scarp on the right side. The active layer was composed of alternating sand-silt-clay deposits. Its detachment happened along the sand-clay interface, thus the shear surface was composed of clay. Detached blocks of landslide body with preserved background vegetation had vertical walls approximately $80 \mathrm{~cm}$ in height (that indicated the depth of the active layer).

According to existing aerial photographs, the second landslide (L2) detached around 1980. This date is also supported by the dendrochronological analysis of willow stem cuttings. The failure occurred within the run-off depression on approximately $5^{\circ}$ steep north-northwest-facing slope. L2 was $150 \mathrm{~m}$ long with a $120 \mathrm{~m}$ shear surface. The active layer was composed of silty deposits underlain by clay, over which the sliding occurred. So, the shear surface was composed of clay. Along the lateral sides of the landslide, sandy-silty deposits had accumulated above the clay on the shear surface. This section was desiccated and very eroded, which resulted in a hummocky appearance. On more elevated sides with surficial sandy deposits, background vegetation surrounding both L1 and L2 was represented by dwarf shrub-moss-lichen (Cladonia uncialis, Bryocaulon divergens, Spherophorus globosus, Ochrolechia frigida) tundra (see Table 2 for the list of vascular plant species and mosses), distinguished as subassociation Ledetosum decumbens (association Salicetum nummulariae, alliance Luzulo-Festucion rubrae). Low willow (Salix glauca)-sedge-moss moist tundra along the lower side on peat and loamy surficial deposits was classified as subassociation Caricetosum arctisibirice (association POO-Caricetum concolor, alliance Equiseto-Salicion glaucae) (Table 1, 2).

According to available aerial photographs, landslide 3 (L3) detached before 1965, most likely in 1957 as the dendrochronological analysis suggested. It is located in a shallow depression on the gentle $\left(3^{\circ}\right)$ western slope of the creek valley (approximate dimensions: length $100 \mathrm{~m}$, width $80 \mathrm{~m}$ ). The active layer was formed by alternating silt and loam; sliding occurred over clay, and the shear surface was clay. The adjacent undisturbed hilltop was occupied by Salix glauca-Betula nana-Carex arctisibirica -moss tundra (subassociation typicum, association Bistorto-Betuletum nanae) (Table 1).

Landslide 4 (L4) is approximately 1000 years old, as determined by ${ }^{14} \mathrm{C}$ dating. Its movement range was estimated as $150 \mathrm{~m}$. Willow shrub com- 


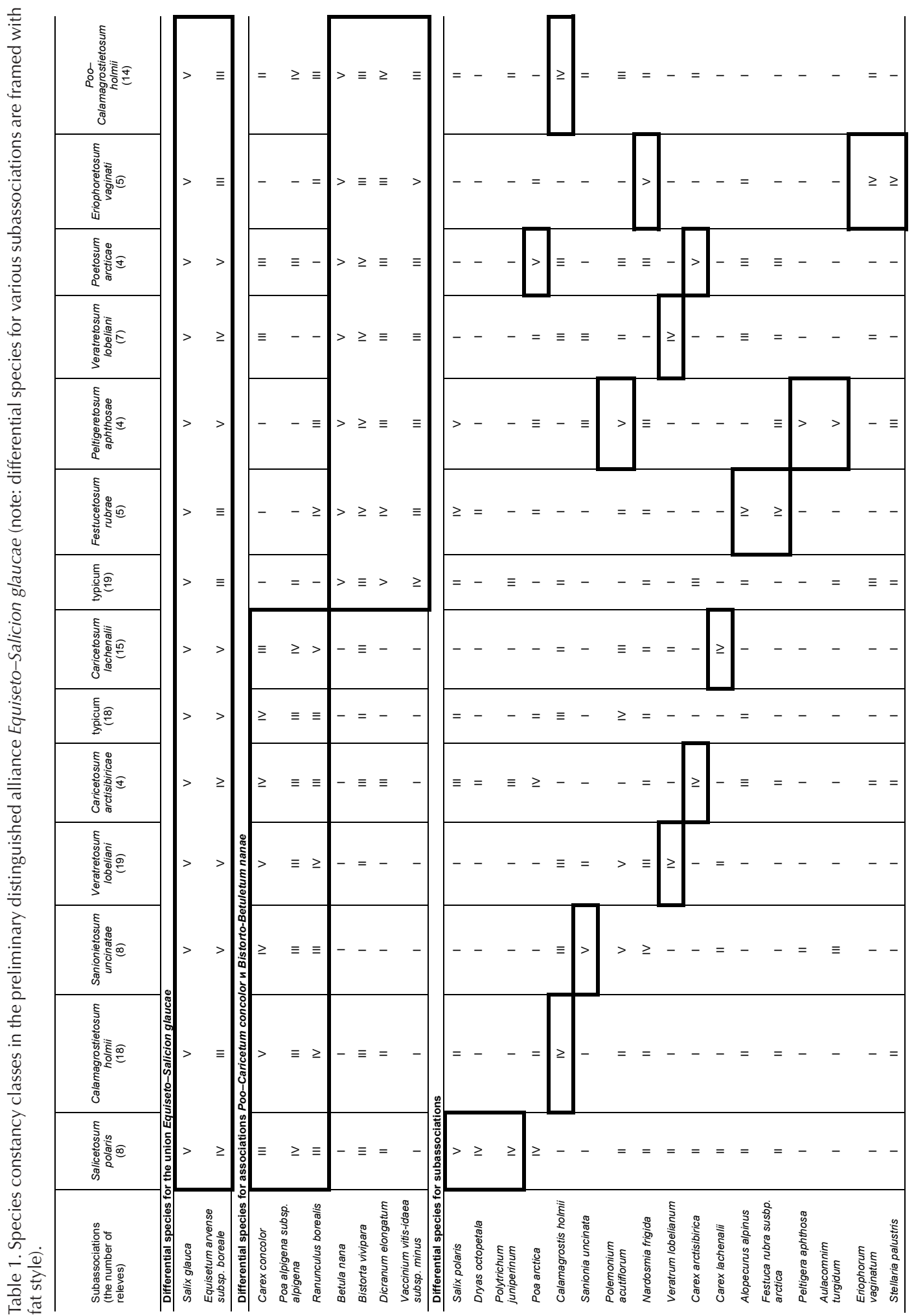


munities with well-developed moss cover occupied the slopes of the landslide cirque on the valley side. The hilltop was occupied by Salix nummularia dominated community of the same type as on sandy soil near L1 and L2, belonging to subassociation Ledetosum decumbens.

\section{Results}

\section{Vegetation on young landslides}

The shear surface of any young, fresh landslide is particularly uneven. Due to ongoing erosion, some sections became convex and very dry with hummocky nano-relief while others became more convex and wet, and run-off or ice-wedge thaw rills formed. Revegetation starts in the areas most favourable for plant growth, where germinating seedlings get some shelter, e.g. a narrow stripe along the scarp and around detached blocks or along the run-off rills. Two years after the detachment total vegetation cover on the shear surface was $<1 \%$. However, in comparison to adjacent tundra areas, the set of species was more diverse with 20 vascular plant species versus $12-14$ and 19 species of green mosses versus 10-15 (Table 2).

Approximately half of the species colonizing the shear surface were absent in adjacent communities (Deschampsia borealis, Puccinellia sibirica, Artemisia tilesii, Tripleurospermum hookeri, Senecio congestus, also pioneer mosses Bryum spp, Ceratodon purpureus, Dicranella crispa, Distichum capillaceum, Funaria hygrometrica, Pohlia proligera, Hennediella heimii, Leptobryum pyriforme). Equisetum boreale and few graminoids from adjacent communities were recorded as well (Table 2). In this initial stage, Deschampsia and Equisetum were the most active colonizers. On displaced blocks of the landslide body, initial tundra communities were present, however shrubs (Betula nana, Salix glauca) and typical tundra mosses had poor vitality. In contrast, the abundance of Equisetum and grasses increased slightly.

By 2012, sparse grass-dominated pioneer vegetation, preliminarily classified as association AlOpecuretum pratensis, occupied the whole shear surface with total PC $=50 \%$. The surface was a mosaic of patches dominated by differing pioneer species, occupying various nano-relief sections of the shear surface. Very similar patterns were observed and mapped in 1991 on L2 (see Fig. 3). De- schampsia borealis predominated overall, however in somewhat wetter concave sections in the central part of the shear surface Puccinellia sibirica ( $\mathrm{PC}=40 \%$ ) was the most abundant. On peripheral parts of the shear surface, Calamagrostis holmii, Festuca rubra, Alopecurus alpinus, Poa alpigena subsp. colpodea (PC approx. 50\%) were growing vigorously. In the shallow and wide distal portions of run-off rill, a wet meadow community had established with Dupontia fisheri, Eriophorum scheuchzeri, Calamagrostis neglecta and Poa alpigena subsp. colpodea (PC up to 90\%). Similar patchy mosaic patterns were also recorded on spatial anthropogenic disturbances, for example, in sand burrow pits (Sumina 2013).

All herbs mentioned in 1991 were found in 2012, but in solitary abundance and mainly on the peripheral parts of the shear surface. Obligate halophyte Carex glareosa (an indicator of saline grounds) was recorded on L1 and practically on all other landslides which occurred in 1989. Mosses on the shear surface formed a thin and non-continuous (PC 30\%) cover (Table 3). All the above mentioned pioneer mosses were recorded again in 2012, but there were also several new species, common in shrub communities (Drepanocladus aduncus, D. polygamus, Sanionia uncinata, Brachythecium jacuticum, B. turgidum) (Table 2 and 3). Mosses play an important role in revegetation and stipulate the formation of an organic horizon, and after 20 years it had established with a depth of $0.5-1 \mathrm{~cm}$. Active regeneration of willows (PC 2-3\%) was recorded mainly from seeds (numerous seedlings up to $3 \mathrm{~cm}$ height were noted), and around the small, almost completely washed-out displaced blocks, vegetative growth (up to $15 \mathrm{~cm}$ high) was noted. This pattern was observed on all landslides from 1989.

The main part of the landslide body had recovered completely after 20 years and was occupied by rather wet (due to changes in drainage) graminoids (Eriophorum polystachion, Carex concolor, Calamagrostis holmii) -dominated community with low (height 30-40 cm) willows (subassociation Calamagrostietosum holmii, association Poo-Caricetosum concolor) (Table 1, 2). There were notable changes in PC of different plant functional groups whereas total PC reached the same value as in the undisturbed community (Table 3). Peripheral parts of the landslide body bordering undisturbed foothills were occupied by a dwarf birch-low willow community with herbs (Ranunculus borealis, Bistorta vivipara) and grasses (Festuca rubra subsp. arctica, Poa alpigena, 
Table 2. List of vascular plant species and mosses found on different morphological elements of landslides of various ages and in adjacent background communities (note: T1 = background Salix nummularia-Carex arctisibirica -moss- lichen tundra communities present around L1, L2 and L4 on well-drained sites; T2 = background Salix glauca-Eriophoprum polystachion dominated tundra; L1, L2, L3, and L4 = studied landslides of different age; SS = shear surface and LB = landslide body; Projective cover\% of species is given for 1991/2012 for L1, L2 and L3, for T1 and T2 no changes were found, only value for 1991 is given and for L4 data from 2012; ' +' means presence, $<<1 \%$, '-' = absence).

\begin{tabular}{|c|c|c|c|c|c|c|c|c|c|c|}
\hline & \multicolumn{10}{|c|}{ Site } \\
\hline Species name & T1 & T2 & L1_SS & L1_LB & L2_SS & L2_LB & L3_SS & L3_LB & L4_SS & L4_LB \\
\hline $\begin{array}{l}\text { Equisetum arvense } \\
\text { subsp.boreale }\end{array}$ & 1 & & $+/+$ & $-/+$ & $+/+$ & $+/+$ & $5 / 10$ & $+/ 2$ & 15 & 20 \\
\hline Alopecurus alpinus & + & + & $+/+$ & & $+/+$ & $+/+$ & $+/ 1$ & $2 / 5$ & + & \\
\hline Arctagrostis latifolia & & + & $+^{1-}$ & $+/+$ & & & $+/+$ & & & \\
\hline Arctophila fulva & & & $-1+$ & & $-/+$ & & & & & \\
\hline Calamagrostis holmii & 2 & 3 & $-/ 3$ & $3 / 20$ & $-/ 5$ & $+/ 3$ & 2/10 & $5 / 5$ & + & 5 \\
\hline C. neglecta subsp.groenlandica & & + & $+/+$ & $+/ 2$ & $+/+$ & & $+/+$ & $+/ 3$ & & \\
\hline Deschampsia borealis & & & $+/ 40$ & $1+$ & $25 / 40$ & $+/+$ & $+/+$ & $5 / 3$ & & \\
\hline Dupontia fisheri & & & $-/ 3$ & & $3 / 15$ & & $5 / 10$ & & & \\
\hline Festuca ovina & 1 & + & $+/+$ & & $-/+$ & $+/+$ & & $+/+$ & & + \\
\hline Festuca rubra subsp.arctica & + & & $+/+$ & $1+$ & $-1+$ & $+/+$ & $+/+$ & $+/ 2$ & + & \\
\hline Phippsia concinna & & & $+/-$ & & $+/-$ & & & & & \\
\hline Poa alpigena subsp.alpigena & 3 & & $-/+$ & $1+$ & & $+/+$ & $+/+$ & $5 / 3$ & + & + \\
\hline$P$. alpigena subsp.colpodea & & & $-/ 1$ & & $1 / 10$ & & $+/+$ & & + & \\
\hline Poa arctica & 1 & + & $-/+$ & $+/+$ & & $+/+$ & & & + & + \\
\hline Puccinellia sibirica & & & $+/ 15$ & & $20 / 10$ & & & & & \\
\hline Trisetum spicatum & & & & & $+/-$ & & & & + & \\
\hline Carex arctisibirica & 10 & 5 & $+/+$ & $2 /+$ & & $+/ 2$ & & & + & \\
\hline Carex lachenalii & & & & & & & $-/ 2$ & & 5 & \\
\hline Carex concolor & & + & & $+/ 10$ & $5 / 10$ & & $10 / 20$ & & 30 & 10 \\
\hline Carex glareosa & & & $-1+$ & & $-/ 1$ & & $2 / 5$ & & & \\
\hline Eriophorum polystachion & & 40 & & $30 / 30$ & $5 / 10$ & $+/ 10$ & $20 / 30$ & $5 / 20$ & & \\
\hline Eriophorum scheuchzeri & & & $-1+$ & & $1 / 3$ & & $+/+$ & & + & \\
\hline Luzula confusa & + & & $+/-$ & & & & & & + & \\
\hline Juncus castaneus & & & & & $+/+$ & & & & & \\
\hline Veratrum lobelianum & & & & & & & & & + & 1 \\
\hline Salix glauca & 5 & 15 & $-/ 1$ & $15 / 20$ & $+/ 5$ & $15 / 20$ & $+/ 5$ & $5 / 15$ & 30 & 60 \\
\hline Salix lanata & & + & & $+/+$ & & $+/+$ & $+/+$ & $+/ 5$ & & \\
\hline Salix nummularia & 30 & + & & & & $+/+$ & & & & \\
\hline Salix polaris & & 7 & & & & $3 / 5$ & $-/+$ & & & \\
\hline Betula nana & 5 & 15 & & $10 / 5$ & & $5 / 5$ & & $+/+$ & + & + \\
\hline Bistorta vivipara & & + & $+^{\prime-}$ & $+/+$ & & $+/+$ & $+/+$ & $+/+$ & + & + \\
\hline Rumex arcticus & & & & & & & & & + & \\
\hline Stellaria peduncularis & + & + & $+/+$ & $+/+$ & & $+/+$ & $-1+$ & & + & + \\
\hline Cerastium jenisejense & & & & & & & & & + & + \\
\hline Trollius asiatica & & & & & & & & & + & \\
\hline Ranunculus borealis & & & $+/+$ & $+/+$ & $-1+$ & & $-1+$ & $+/+$ & 10 & + \\
\hline Ranunculus hyperboreus & & & & & $+/+$ & & & & & \\
\hline Cardamine pratensis & & & & & $-1+$ & & $-1+$ & & & + \\
\hline Draba hirta & & & $+/-$ & & & & & & & \\
\hline Dryas octopetala & + & & & & & & & & & \\
\hline Saxifraga cernua & & & & & & & $-1+$ & & + & + \\
\hline $\begin{array}{l}\text { Parnassia palustris } \\
\text { subsp.neogaea } \\
\text { Pachypleurum alpinum }\end{array}$ & & & & & $-1+$ & $-/+$ & $-1+$ & & $\begin{array}{l}+ \\
+\end{array}$ & \\
\hline $\begin{array}{l}\text { Vaccinium vitis-idaea } \\
\text { subsp.minus }\end{array}$ & 5 & 2 & & $2 /+$ & & $3 /+$ & & & & \\
\hline $\begin{array}{l}\text { V.uliginosum subsp. } \\
\text { microphyllum }\end{array}$ & + & & & $+/-$ & & $+/+$ & & & & \\
\hline Pyrola grandiflora & & & & $+/+$ & & $+/ 1$ & $-1+$ & & & \\
\hline Polemonium acutiflorum & & + & $-/+$ & & & $+/ 1$ & $+/ 1$ & $-1+$ & 3 & 1 \\
\hline Myosotis asiatica & & & $+/-$ & & & & & & + & \\
\hline $\begin{array}{l}\text { Pedicularis sudetica subsp. } \\
\text { interioroides }\end{array}$ & & & $-/+$ & & $-1+$ & & $+/+$ & $-1+$ & + & \\
\hline Valeriana capitata & + & & $+/+$ & $+/+$ & & $+/+$ & & & + & + \\
\hline Artemisia tilesii & & & $+/+$ & & & & & & + & + \\
\hline
\end{tabular}


Table 2. (continued)

\begin{tabular}{|c|c|c|c|c|c|c|c|c|c|c|}
\hline $\begin{array}{l}\text { Nardosmia frigida } \\
\text { Senecio congestus } \\
\text { Tripleurospermum hookeri }\end{array}$ & & + & $\begin{array}{l}+/+ \\
+/+ \\
+/ 1\end{array}$ & I+ & $\begin{array}{c}-/+ \\
+/- \\
10 / 5\end{array}$ & & $-/+$ & & + & + \\
\hline Aulacomnium turgidum & 1 & 5 & $+/+$ & $5 / 5$ & $-/+$ & $+/ 2$ & $+/ 2$ & +/+ & + & + \\
\hline Aulacomnium palustre & & + & & $+/ 5$ & $-/+$ & & & $+/+$ & + & + \\
\hline Bartramia ithyphylla & + & & $+/+$ & & & & & & & \\
\hline Brachythecium mildeanum & & & & & & & $+/+$ & & & + \\
\hline Brachythecium jacuticum & & & $-/+$ & & & & $-/ 2$ & $+/+$ & 20 & 10 \\
\hline Brachythecium turgidum & & & $-/+$ & & $+/+$ & & $+/+$ & $+/+$ & & + \\
\hline Bryum knowltonii & & & $+/ 10$ & & $10 / 15$ & & & & & \\
\hline Bryum teres & + & + & $+/+$ & & $+/ 1$ & & & & & \\
\hline Bryum pseudotriquetrum & & & & & & $+/+$ & & $+/+$ & + & + \\
\hline Calliergon cordifolium & & & & & & & $+/+$ & & + & \\
\hline Campylium stellatum & & & $-/+$ & & & & & $+/+$ & 5 & \\
\hline Ceratodon purpureus & & & $+/ 5$ & & $10 / 10$ & $2 /+$ & $+/+$ & $+/+$ & & \\
\hline Conostomum tetragonum & + & & & & & & & & & \\
\hline Dichodontium crispa & & & $+/ 5$ & & + & & & & & \\
\hline Dicranella palustris & & & & & $-/+$ & & & & & \\
\hline Dicranella subulata & & & $+/-$ & & & & & & & \\
\hline Dicranum elongatum & 10 & 20 & & $10 /+$ & & $10 / 5$ & & & & \\
\hline Distichium capillaceum & & & & & $+/ 1$ & & & & + & + \\
\hline Drepanocladus aduncus & & & $-/+$ & & $+/ 2$ & & $-/+$ & $-/+$ & & \\
\hline Drepanocladus arcticus & & & & & + & & $15 / 25$ & $5 / 10$ & + & + \\
\hline Drepanocladus polygamus & & & $-/+$ & & & & $-/+$ & & & \\
\hline Eurhynchiastrum pulchellum & & & $+/+$ & & & & & & & \\
\hline Funaria hygrometrica & & & $+/ 5$ & & $5 /+$ & & & & & \\
\hline Hennediella heimii var. arctica & & & $+/ 2$ & & $+/-$ & & & & & \\
\hline $\begin{array}{l}\text { Hylocomium splendens var. } \\
\text { obtusifolium }\end{array}$ & 5 & 10 & $+/+$ & $5 / 10$ & $-/+$ & 10/15 & $+/ 2$ & $-/+$ & 30 & 50 \\
\hline Leptobryum pyriforme & & & $+/ 10$ & $+/+$ & $15 / 20$ & & & & & \\
\hline Philonotis fontana & & & & & & & & & & + \\
\hline Plagiomnium ellipticum & & & & 1+ & $-/+$ & & & $-/+$ & & \\
\hline Plagiothecium denticulatum & & & & & & & & & + & \\
\hline Pogonatum dentatum & & & $+/+$ & & & & & & & \\
\hline Pohlia andrewsii & & & $+/+$ & & $+/+$ & & & & & \\
\hline Pohlia cruda & & & $+/+$ & & & & & & & \\
\hline Pohlia crudoides & & & & & & $+/+$ & & & & \\
\hline Pohlia drummondii & & & $+/+$ & & & & & & & \\
\hline Pohlia filum & & & $+/+$ & & $+/+$ & & & & & \\
\hline Pohlia nutans & & & & $1+$ & & $+/+$ & + & $+/+$ & + & \\
\hline Pohlia proligera & & & $+/+$ & & $+/+$ & & & & & \\
\hline Polytrichastrum alpinum & & & & & & + & + & & + & \\
\hline Polytrichum juniperinum & + & 5 & $+/+$ & $1 / 5$ & & & & & + & + \\
\hline Polytrichum hyperboreum & 20 & & & & $-/+$ & 10/15 & & & & \\
\hline Polytrichum piliferum & + & & & & & & & & & \\
\hline Psilopilum laevigatum & & & $+/+$ & & $+/-$ & & & & & \\
\hline Racomitrium lanuginosum & 3 & & & & & & & & & \\
\hline Rhizomnium pseudopunctatum & & & $-/+$ & & $-/+$ & & & & & + \\
\hline Sanionia uncinata & + & 3 & $-/+$ & $+/ 5$ & $+/ 15$ & $+/ 3$ & $50 / 65$ & $20 / 30$ & 50 & 40 \\
\hline Sciuro-hypnum latifolium & & & & & & & & & + & + \\
\hline Straminergon stramineum & & & $-1+$ & & $-/+$ & & $-/+$ & $+/+$ & + & \\
\hline Syntrichia ruralis & & & $+/+$ & & & & & & & \\
\hline Tomentypnum nitens & & & & & $-/+$ & & & & + & + \\
\hline Warnstorfia exannulata & & & $-/+$ & & $-/+$ & & $-/+$ & & & \\
\hline Liverworts & 10 & + & & & $+/ 5$ & $5 / 3$ & $5 / 2$ & + & + & + \\
\hline
\end{tabular}


Alopecurus alpinus) classified as subassociation Festucetosum rubrae (association Bistorto-Betuletum nanae) (Table 1, 2).

\section{Vegetation on landslides formed $30-40$ years ago}

The patchy pattern observed on L2 in 1991 was very similar to that described on L1 in 2012 (Fig. 3). An increase in total PC was observed on the shear surface of L2 (Table 3). By 2012, the shear surface of L2 became smoother, more concave; sandy deposits were washed out and pioneer vegetation had become more uniform. A mosaic pattern with patches of various predominating species was still notable in 2012, though the coverage of different species changed from 1991. PC generally increased for Deschampsia borealis, Poa alpigena and Dupontia fisheri but decreased for Puccinellia sibirica and Tripleurospermum hookeri (Table 3). Numerous willow seedlings were recorded, though their total coverage was only around 5\%. Mosses had spread over almost the entire shear surface (Table $3)$. Along with the same pioneer mosses as previously recorded (Table 2), in 2012 Sanionia uncinata, Tomentypnum nitens and Drepanocladus aduncus were found not only in peripheral, but also in central parts of the shear surface.

Due to the presence of species of both earlier and later successional stages, the total number of species on the shear surface increased from 34 (in 1991) to 51 (in 2012) (Table 3). Interestingly, vegetation on the detached blocks of tundra had not changed since 1991, but in 2012 plants had better vitality than in 1991. Tundra mosses (Hylocomium splendens, Polytichum juniperinum, Aulacomnium turgidum) had completely recovered on the blocks, and lichens (Peltigera spp.) had become abundant.

\section{Vegetation on old landslides}

In 1991, the distal part of the landslide body of L3 was covered by a graminoid-dominated community with willows with rather fragmentary moss cover. By 2012 moss cover increased mainly due to the spreading of Sanionia uncinata, but also, typical for zonal tundra mosses, Aulacomnium turgidum and Hylocomnium splendens became more abundant (Table 2, 3). Lichens were almost wholly absent in 1991, but had become fairly abundant by 2012 , in particular Peltigera spp. and Stereocaulon sp. Also liverworts (especially Lophosia spp.) were abundant both in 1991 and 2012. Such communities are regarded as subassociation Peltigeretosum aphtosae (Table 1, 4).

The shear surface of L3 in 1991 was completely covered by vegetation. Both the number of species and coverage of bryophytes increased by 2012 . Species indicating mineral enrichment, including Campylium stellatum, Tomentypnum nitens, Aulacomnium turgidum became abundant, though Sanionia uncinata was still predominating. The latter is a differential species for the subassociation Sanionietosum uncinatae, distinguished mainly on the bodies of old landslides, but on L3 it was also spreading on the periphery of the shear surface. Moss turf had reached 3-4 cm thickness.

Table 3. Projective cover percent (PC\%) of various plant functional groups and the number of vascular plant species and green moss species on the studied landslides and in background communities (note: L1, L2, L3, and L4 = studied landslides of different age; SS = shear surface and LB = landslide body; PC\% is given for 1991/2012, for L4 only for 2012; ' + ' means presence, $<<1 \%$, '-' means absence).

\begin{tabular}{l|c|c|c|c|c|c|c|c|c|c}
\hline & T1 & T2 & L1_SS & L1_LB & L2_SS & L2_LB & L3_SS & L3_LB & L4_SS & L4_LB \\
\hline Total PC $\%$ & $90 / 90$ & $95 / 95$ & $1 / 50$ & $80 / 95$ & $50 / 70$ & $80 / 90$ & $90 / 95$ & $80 / 95$ & 100 & 100 \\
\hline $\begin{array}{l}\text { PC\% of shrubs and dwarf } \\
\text { shrubs }\end{array}$ & $40 / 40$ & $40 / 40$ & $-/(5)$ & $35 / 30$ & $+/(5)$ & $30 / 20$ & $15 / 25$ & $30 / 40$ & 30 & 60 \\
\hline PC\% of graminoids & $10 / 10$ & $40 / 40$ & $<1 / 50$ & $40 / 70$ & $40 / 70$ & $20 / 60$ & $50 / 60$ & $30 / 40$ & 40 & 30 \\
\hline PC\% of mosses & $40 / 40$ & $60 / 60$ & $+/ 30$ & $60 / 40$ & $5 / 30$ & $35 / 50$ & $70 / 80$ & $30 / 60$ & 80 & 80 \\
\hline PC\% of lichens & $30 / 30$ & $10 / 10$ & $-/-$ & $7 /+$ & $-/+$ & $+/ 5$ & $+/+$ & $+/ 5$ & 1 & 3 \\
\hline $\begin{array}{l}\text { Number of vascular plant } \\
\text { species }\end{array}$ & $17 / 17$ & $20 / 20$ & $21 / 26$ & $18 / 22$ & $16 / 26$ & $23 / 23$ & $19 / 28$ & $14 / 16$ & 30 & 18 \\
\hline Number of green mosses & $11 / 11$ & $7 / 7$ & $21 / 29$ & $7 / 8$ & $18 / 25$ & $10 / 12$ & $10 / 15$ & $11 / 14$ & 16 & 15 \\
\hline
\end{tabular}


Fig. 3. Map of landslide 2 showing the patchy pattern of revegetation on young landslides. Patches: 1) not shown, $0.5 \mathrm{~m}$ width stripe along the scarp Equisetum boreale dominated; 2) Deschampsia borealis dominated; 3) Puccinellia sibirica dominated; 4) Tripleurospermum hookeri on the remnants of sandy deposits on the shear surface; 5) slightly concave Alopecurus alpinus dominating; 6) gently sloping run-off part with Eriophorum polystachion, active regeneration of Salix glauca and abundant mosses (Sanionia uncinata, Tomentypnum nitens, Dicranella crispa); 7) wide run-off trough with Puccinellia sibirica, Deschampsia borealis and without mosses; 8) shallow distal part of the trough with Equisetum boreale, $\mathrm{PC}=80 \%$; 9) and 10 ) landslide body with Salix glauca-Calamagrostis holmiiCarex arctisibirica-moss tundra; and 11) deformed during detachment frontal part of landslide body with transformed Salix reptans-Deschampsia borealis tundra with degrading moss turf.

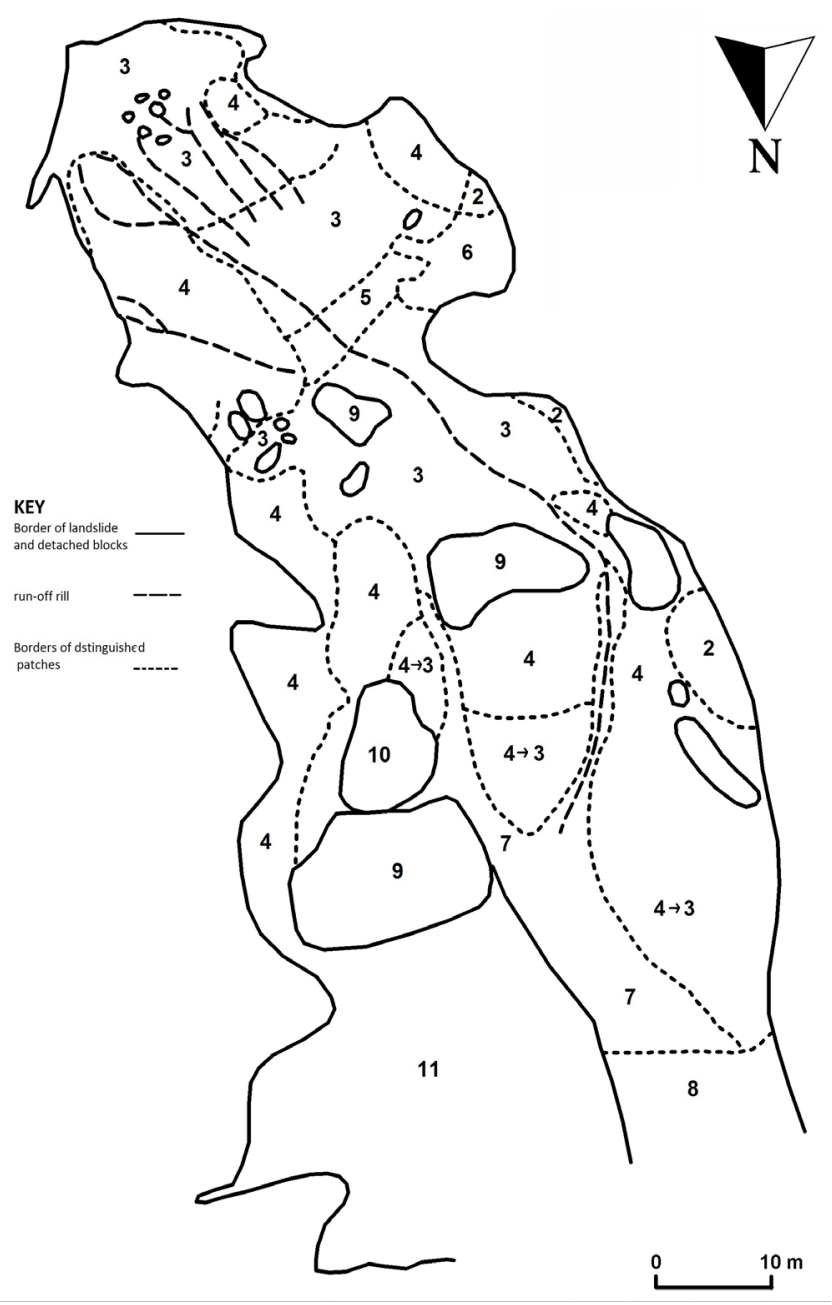

The main part of the shear surface was gently concave covered by a Carex concolor dominated community with the presence of Carex glareosa and abundant Dupontia fisheri, Calamagrostis holmii classified as subassociation typicum (ass. PooCaricetum concolor) (Table 1, 4). In 2012, active willow growth was recorded in comparison to sparse willow seedlings in 1991 (Table 2, 3). The community on the shear surface had become more similar to those on the landslide body. Already in 1991 there was a principal change in moss composition at L3 in comparison to younger stages, and these changes were even more pronounced in 2012; pioneer species were almost completely replaced by species characteristic of willow commu- nities on slopes or at footslopes with Sanionia uncinata as the most important dominant species. Aulacomnium turgidum, Hylocomium splendens, and Polytrichastrum alpinum were recorded both on peripheral parts of the shear surface and on the landslide body (Table 2).

\section{Vegetation on ancient landslides}

On L4 somewhat more concave parts of the slope were recognized as an ancient shear surface which was now completely covered by a willow-sedge-horsetail-moss (Sanionia uncinata, Brachythecium jacuticum) community with tall (height $>1 \mathrm{~m}$ ) Salix glauca and $S$. lanata 
with developed herbaceous and moss layers (Table 2, 3). The community was classified as subassociation Caricetosum lachenalii with Carex lachenalii as a differential species and with abundant Carex concolor, Equisetum boreale, and Bistorta vivipara (Table 1, 2, 3). Carex lachenalii normally grows on snow-beds and its presence shows that there is plentiful snow on this surface.

Nearby on the somewhat convex surface, which was assumed to be the central part of the ancient landslide body, another kind of willowmoss community with abundant herbs (Trollius asiatica, Veratrum lobelianum, Ranunculus borealis, Polemonium acutiflorum etc.) was described as subassociation Veratretosum lobeliani with Veratrum lobelianum as a differential species (Table 1, 2, 3). Sanionia uncinata and Hylocomium splendens were dominant in well-developed moss cover (Table 2).

\section{Salt content in groundwater on landslide affected slopes.}

Samples for the determination of salt concentration in groundwater were collected under various plant communities located on different morphological elements of the landslides of various ages (including those described here as well as several other failures from 1989 and ancient landslides).

The total salt concentration and concentration of different ions were analyzed. Though different sectors of a landslide-affected slope are interconnected by groundwater flows and surface runoff (Fig. 4), the presence of geochemical barriers causes variations in the concentration and redistribution of ions, especially anions. Therefore, the differing morphological elements of a landslide and even their specific sections (central vs. peripheral) are characterized by different concentrations and compositions of ions.

Surfaces occupied by different plant communities can be organized according to decreases in salt concentration in groundwater in the following sequence: central parts of a shear surface (the highest salt concentration), peripheral parts of a shear surface, central parts of a landslide body and peripheral parts of a landslide body (the lowest salt concentration) (Table 4, Fig. 5). The central parts of the shear surfaces of the youngest and oldest landslides returned the most significant differences in salt concentrations whereas pe-

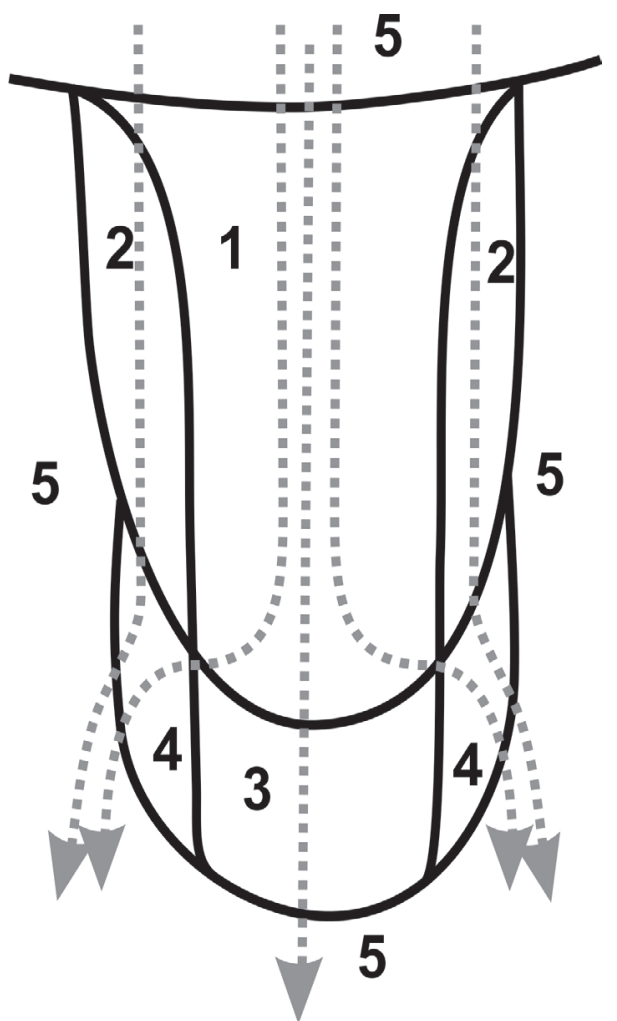

Fig. 4. Schematic map of groundwater flows under a landslide (note: black line = border of different elements (1-4) of a landslide; dashed arrow lines $=$ ground water routes; 1 = central parts of shear surface; $2=$ peripheral parts of shear surface; 3 = central parts of landslide body; 4 = peripheral parts of landslide body; and 5 = stable slopes).

ripheral parts of the landslide bodies of the same categories of landslides showed less contrast. It is important to note that for landslides of the same age there was relatively little variation in total salt concentration in groundwater in peripheral parts of the shear surface and in central parts of the landslide body.

\section{Discussion}

The depth of the active layer varies from 60 to 120 $\mathrm{cm}$ whereas soil horizons usually do not extend deeper than $30 \mathrm{~cm}$. Therefore, the recovery of shear surfaces is ongoing as a primary succession, which refers to re-vegetation of barren mineral surfaces (Walker \& del Moral 2003). However, on a 


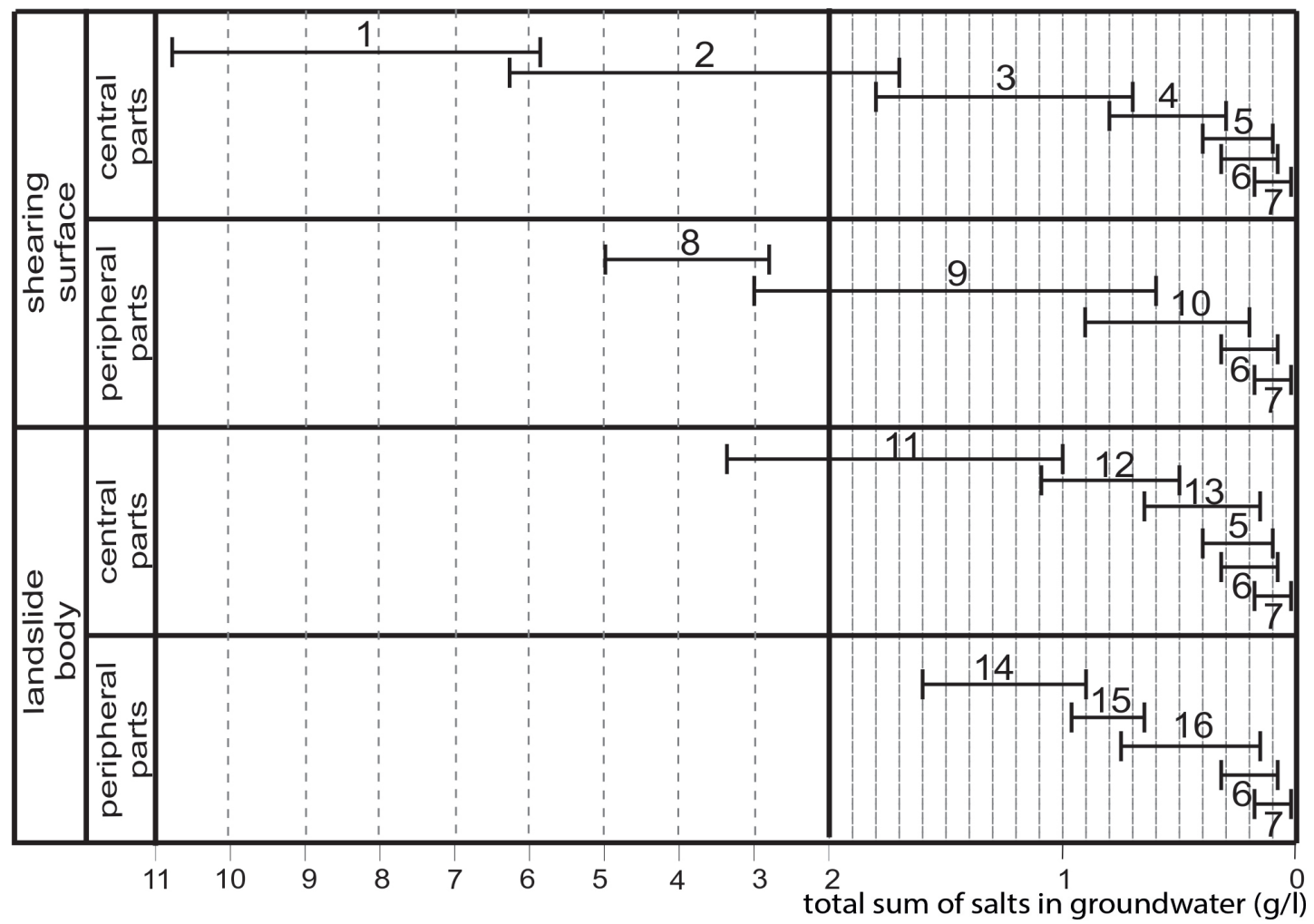

Fig. 5. The distribution of syntaxa in different habitats in relation to total salt content (note: $(1)=$ subassociation belongs to ass. Poo-Caricetum concolor; $(2)=$ subassociation belongs to ass. Bistorto-Betuletum nanae; 1 . ass. Alopecuretum pratensis; 2. subass. Caricetosum arctisibiricae (1); 3. subass. typicum (1); 4. subass. Caricetosum lachenalii (1); 5. subass. Salicetosum polaris (1); 6. subass. typicum (2); 7. ass. Vaccinio-Betuletum nanae, 8. subass. Calamagrostietosum holmii (1); 9. subass. Sanionietosum uncinatae (1); 10. subass. Veratretosum lobeliani (1); 11. subass. Festucetosum rubrae (2); 12 . subass. Peltigeretosum aphthosae (2); 13.subass. Veratretosum lobeliani (2); 14. subass. Poetosum arcticae (2); 15. subass Eriophoretosum vaginati (2); and 16. subass. Poo-Calamagrostietosum holmii (2).

landslide body secondary succession is taking place. Such processes were also recorded on anthropogenically disturbed sites in southern Yamal, including gravel or sand excavation pits where various pioneer communities were described (Sumina 2013). Only local flora species are participating in the recovery of natural and anthropogenic disturbances in Yamal (Rebristaya et al. 1995; Khitun 1997; Sumina 2013).

In the process of revegetation on exposed mineral surfaces in Low Arctic Yamal plains during the first 30 years, grass-dominated pioneer communities form on shear surfaces. Though it was thought that pioneer vegetation is similar throughout the Arctic, many studies have revealed that these com- munities are very region-specific (Forbes 1994; Khitun 1997; Cannone et al. 2010; Sumina 2013). In Yamal, the most important colonizer is Deschampsia borealis, whereas other grasses and especially herbs are more variable in their abundance from year to year. In other parts of the Arctic, pioneer communities on shear surfaces can incorporate the larger numbers and abundance of herbs (Cannone et al. 2010).

On gently sloping, smooth and usually somewhat wetter frontal parts of shear surfaces, wet meadows with Carex concolor, Eriophorum scheuchzeri and Dupontia fisheri develop. After 15-20 years, the active growth of willows, germinated from wind dispersed seeds, starts on the shear 
Table 4. Confidence intervals of salt and ion concentrations in groundwater of landslide sections, occupied by different syntaxa (note: * for comparison data for non affected by landslide process stable slopes is given; ** not enough data for calculating confidence interval, mean for 3 samples is given; (1) subassociations belonging to association Poo-Caricetum concolor; (2) subassociations belonging to association Bistorto-Betuletum nanae; LB= landslide body and SS= shear surface).

\begin{tabular}{|c|c|c|c|c|c|c|c|c|c|}
\hline & & Syntaxon and age of surface & $\begin{array}{c}\text { Total salts } \\
(\mathrm{g} / \mathrm{l})\end{array}$ & $\begin{array}{l}\mathrm{Cl}^{-} \\
(\mathrm{g} / \mathrm{l})\end{array}$ & $\begin{array}{c}\mathrm{SO}_{4}{ }^{2-} \\
(\mathrm{g} / \mathrm{l})\end{array}$ & $\begin{array}{l}\mathrm{Ca}^{2-} \\
(\mathrm{g} / \mathrm{l})\end{array}$ & $\begin{array}{l}\mathrm{Mg}^{2+} \\
(\mathrm{g} / \mathrm{l})\end{array}$ & $\begin{array}{c}\mathrm{K}^{+} \\
(\mathrm{g} / \mathrm{l})\end{array}$ & $\begin{array}{l}\mathrm{P}_{2} \mathrm{O}_{5} \\
(\mathrm{~g} / \mathrm{l})\end{array}$ \\
\hline \multirow{3}{*}{\multicolumn{2}{|c|}{$\begin{array}{l}\frac{0}{0} \\
\frac{0}{0} \\
\frac{\mathbb{\sigma}}{\omega} \frac{0}{\omega} \\
\omega\end{array}$}} & Salicetosum polaris (1), stable slope ${ }^{*}$ & $0.13-0.4$ & $0.06-0.08$ & $0.002-0.01$ & $0.002-0.01$ & $0.001-0.009$ & $0.001-0.003$ & $0.18-0.30$ \\
\hline & & typicum (2), stable slope & $0.08-0.31$ & $0.039-0.059$ & $0.014-0.02$ & $0.004-0.014$ & $0.004-0.014$ & $0.004-0.014$ & $0.437-0.457$ \\
\hline & & Vaccinio-Betuletum nanae, stable slope & $0.01-0.18$ & $0.005-0.015$ & $0.012-0.026$ & $0.003-0.011$ & $0.001-0.009$ & $0.001^{* *}$ & $0.001^{\star *}$ \\
\hline \multirow{7}{*}{$\begin{array}{l}\frac{n}{0} \\
\frac{0}{\pi} \\
\frac{0}{0} \\
\frac{\pi}{0} \\
\frac{0}{0} \\
0 \\
0\end{array}$} & \multirow{3}{*}{ 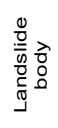 } & Calamagrostietosum holmii (1), young & $1.0-3.4$ & $0.644-0.75$ & $0.166-0.41$ & $0.032-0.052$ & $0.06-0.078$ & $0.012-0.02$ & $0.071-0.093$ \\
\hline & & Sanionietosum uncinatae (1), old & $0.5-1.1$ & $0.092-0.292$ & $0.025-0.035$ & $0.02-0.038$ & $0.025-0.045$ & $0.007-0.017$ & $0.468-0.488$ \\
\hline & & Veratretosum lobeliani (1), ancient & $0.15-0.65$ & $0.072-0.092$ & $0.024-0.03$ & $0.002-0.02$ & $0.007-0.027$ & $0.003-0.009$ & $0.268-0.30$ \\
\hline & \multirow{4}{*}{ 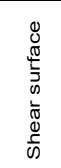 } & Alopecuretum pratensis, young fresh & $5.82-10.7$ & $3.70-3.90$ & $1.00-1.30$ & $0.07-0.17$ & $0.26-0.32$ & $0.062-0.082$ & $0.007-0.027$ \\
\hline & & Caricetosum arctisibiricae (1), young stabilised & $1.7-6.35$ & $1.90-2.10$ & $0.30-0.50$ & $0.07-0.09$ & $0.05-0.15$ & $0.03-0.08$ & $0.037-0.137$ \\
\hline & & typicum (1), old & $0.7-1.8$ & $0.60-1.00$ & $0.03-0.07$ & $0.024-0.064$ & $0.03-0.052$ & $0.019-0.029$ & $0.875-0.915$ \\
\hline & & Caricetosum lachenalii (1), ancient & $0.3-0.8$ & $0.43-0.57$ & $0.009-0.029$ & $0.005-0.025$ & $0.01-0.03$ & $0.003-0.012$ & $0.38-0.52$ \\
\hline \multirow{6}{*}{$\begin{array}{l}\frac{0}{0} \\
\frac{0}{\pi} \\
\frac{0}{\pi} \\
\frac{0}{0} \\
\frac{5}{0} \\
\frac{2}{0} \\
0\end{array}$} & \multirow{3}{*}{ 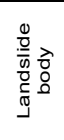 } & Festucetosum rubrae (2), young & $0.9-1.6$ & $0.40-0.60$ & $0.04-0.10$ & $0.051-0.061$ & $0.051-0.061$ & $0.01-0.02$ & $0.055-0.065$ \\
\hline & & Peltigeretosum aphthosae (2), old & $0.64-0.98$ & $0.207-0.407$ & $0.035-0.045$ & $0.041-0.053$ & $0.035-0.051$ & $0.003-0.013$ & $0.376-0.396$ \\
\hline & & Veratretosum lobeliani (2), ancient & $0.17-0.76$ & $0.038-0.138$ & $0.013-0.029$ & $0.004-0.024$ & $0.01-0.03$ & $0.001-0.003$ & $0.224-0.264$ \\
\hline & \multirow{3}{*}{ 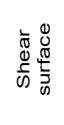 } & Poetosum arcticae (2), young & $2.81-5.0$ & $1.93-2.13$ & $0.197-0.217$ & $0.112-0.212$ & $0.13-0.23$ & $0.015-0.019$ & $0.082-0.182$ \\
\hline & & Eriophoretosum vaginati (2), old & $0.6-3.0$ & $0.92-1.02$ & $0.074-0.114$ & $0.024-0.03$ & $0.034-0.054$ & $0.005-0.015$ & $0.625-0.645$ \\
\hline & & Poo-Calamagrosti-etosum holmii (2), ancient & $0.2-0.91$ & $0.71-0.89$ & $0.075-0.085$ & $0.015-0.025$ & $0.016-0.04$ & $0.001-0.003$ & $0.25-0.35$ \\
\hline
\end{tabular}

surface. Pioneer mosses play an important role in the initial stages of recovery, however transition to common shrub community species occurs at the stage of old landslides. During the 20-year period between surveys on L3, at least 6 very common tundra species (Aulacomnium turgidum, A. palustre, Tomentypnum nitens, Drepanocladus aduncus, Campylium stellatum, Straminergon stramineum) penetrated into the willow-sedge community on the shear surface. This community resembles the ones on the landslide body and in undisturbed tundra in run-off depressions in the creek valley. Subsequent$l y$, no pioneer species were found on ancient shear surfaces. The total number of species on shear surfaces increased over the 20-year period between observations on young and old landslides. Projective cover increased dramatically on L1 over 20 years, whereas for L3 the changes were relatively indiscernible. The Dupontia-dominated community was mostly responsible for the increase of total PC on L2, indicating that wetter sections occupy a larger area in the landslide scar.

Active layer detachment slides dramatically change environmental features; the organic layer is destroyed, the acidity of the upper horizon of the ground changes from $\mathrm{pH} 4.4$ under the tundra turf to $\mathrm{pH} 6$ in exposed saline (salinity 1 to $2 \%$ ) clays. In Yamal and generally in the West Siberian Arctic, the obligate halophyte Carex glareosa is characteristic for landslides and can serve as an indicator of old and ancient landslides. Facultative halophyte Tripleurospermum hookeri is one of the co-dominants in pioneer groupings on young landslides, but it is absent on old and ancient landslides. Not a single dwarf shrub species was recorded on any of the landslides, whereas undisturbed communities surrounding landslides contained Vaccinium vitis-idaea and Salix nummularia - most likely due to elevated salt content preventing their growth.

A combination of dwarf birch-willow tundra (alliance Equiseto-Salicion glaucae), dwarf birch tundra (ass. Vaccinio-Betuletum nanae), sedge-moss tundra (ass. Luzulo-Polytrichetum juniperinum) and all pioneer herbaceous-grass communities (generally referred to ass. Alopecuretum pratensis) are connected with clayey deposits on the slopes of marine terraces and indicate the presence of a landslide process. Classification using the BraunBlanquet method gives more precise differentiation 
between communities on the landslides and defines regularity in their distribution correlated with the age and morphological elements of the landslide. Linear correlation (Pearson correlation coefficient $r>0.7$ ) was revealed between distinguished vegetation units (associations and sub-associations) and their location on certain morphological elements of the landslide. Various syntaxa observed on the slopes were occupying different habitats.

Cluster analysis of syntaxa species composition (Fig. 6) confirmed differentiation of six subdivisions (similarity $>70 \%$ ). Associations Alopecuretum pratensis (pioneer communities on young shear surfaces), Luzulo-Polytrichetum juniperinum (moss-dominated communities of snowbeds on stable slopes) and Vaccinio-Betuletum nanae (communities on hilltops adjacent to landslides) formed each its own group, that reflected their specificity (see Fig. 6). The fourth cluster grouped two syntaxa of association Bistorto-Betuletum nanae and subassociations Festucetosum rubrae and Peltigeretosum aphthosae; these are communities that occupy peripheral parts of young and old landslide bodies. In the fifth cluster, five subassociations of association Bistorto-Betuletum nanae were grouped together: typicum, Veratretosum lobeliani, Poetosum articae, Eriophoretosum vaginati and Poo-Calamagrostietosum holmii. These communities occupied various habitats, including slopes adjacent to landslides, peripheral parts of ancient landslide bodies and shear sur- faces. Finally, the sixth cluster joined all subassociations of association POO-Caricetum concolor. These communities were mainly found on the central parts of shear surfaces and landslide bodies of old and ancient landslides. Associations of alliance Equiseto-Salicion glaucae are characterized by high floristic similarity (> $70 \%$ ), that most likely reflects the ecological and successional connection of these syntaxa.

Communities that were classified as association Poo-Caricetum concolor had a tendency to be found within the central parts of landslide elements, whereas the communities of association BistortoBetuletum were found in the peripheral sections. When initial vegetation is disturbed by a landslide, further vegetation succession will depend on 1) morphological element of the landslide and 2) location (central or peripheral). Succession on central parts of a shear surface is ongoing as primary, whereas on the detached blocks and along the scar as secondary. Data obtained allowed the construction of a succession scheme of vegetation in relation to landslide processes on the slopes of marine terraces in Central Yamal. The longest sequence can be observed on the central parts of shearing surfaces, while in peripheral parts it is shorter. As vegetation is restored, different succession lines merge which reflect the increasing similarity of ecological conditions on different elements of former landslides. Comparisons between the landslide age, structure and succession stage showed that the rate

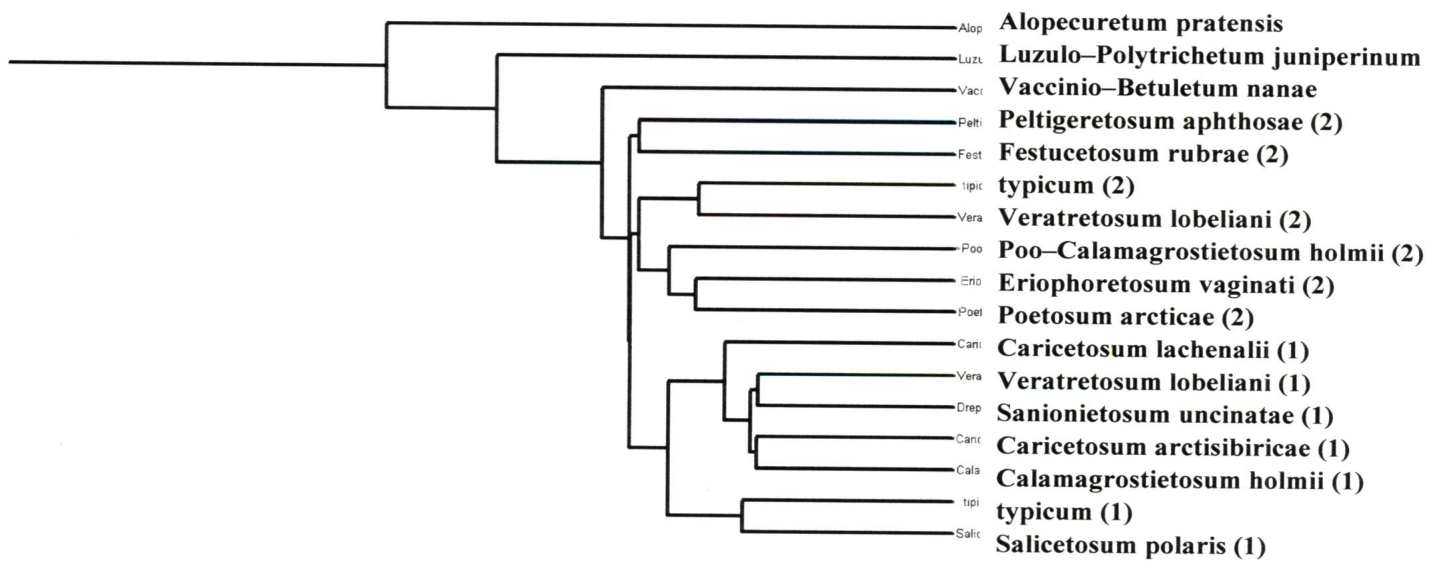

Fig. 6. The dendrogram of similarity of distinguished syntaxa (note: Sørensen similarity coefficient was used, $k=2 \mathrm{c} /(\mathrm{A}+\mathrm{B})$, where $c$ is the number of common in two syntaxa species, $A$ is the number of species in one syntaxon, and $B$ is the number of species in another syntaxon; for the explanation of subassociations, see Fig. 5). 
of succession slows down markedly as it approaches ancient stages. This coincides with general knowledge about the decreased rate of succession as it approaches the climax stage. The data indicate that the period after the merging of various succession lines until achieving sub-climax (and moreover climax) communities require thousands of years to develop. Such longevity of succession changes corresponds to the opinion of other researches, which has given approximates of between 3500-12000 years for primary, and $1500-5000$ years for secondary successions (Razumovskii 1981; Kucherov \& Zagidullina 2001).

Observed ecological sequences according to change in groundwater salt concentrations were the same as those found only according to vegetation data. Canonical correspondence analysis confirmed the importance of salt content in groundwater for vegetation dynamics on the slopes (Fig. 7). Decreases in the sum of salts in groundwater were found on all morphological parts of landslides and correlated with the increase of the time since failure. Usually the concentrations of $\mathrm{Cl}^{-}, \mathrm{Ca}^{2+}, \mathrm{Mg}^{2+}, \mathrm{SO}_{4}^{2-}$ and $\mathrm{K}^{+}$decrease sharply on the young landslides, whereas on the ancient landslides very little decrease was observed. According to radiocarbon dating (Leibman \& Kizyakov 2007) the complete desalinization of marine deposits exposed after detachment and development within a seasonal thaw layer occur over less than 300 years. The presence of obligate halophyte Carex glareosa even on ancient landslides corresponds to findings made by Ukraintseva et al. (2003) regarding variation in salinity on ancient shear surfaces (though values $0.3-0.5 \mathrm{~g} / \mathrm{l}$ prevail on such surfaces, local sites with 4-5 g/l were found).

In contrast to regularities observed in Yamal, vegetation in the Canadian High Arctic did not reflect the differing degrees of desalinization between and within the landslides (Cannone et al. 2010). However, similarly to the Canadian Arctic, the main colonizers in Yamal (not the same as Canadian ones) are also not true halophytic species. Carex glareosa is an important indicator but it is not the main colonizer. The role of herbs (vs. graminoids) in the recovery of landslides (and other disturbances as well) is definitely lower in Yamal than in the Canadian High Arctic. One of the reasons may be that many herbs are truly arctic species (by origin from ancient Eu-Arctic flora) which generally are poorly represented in Yamal, partly due to its geological 'youth,' and partly due to widespread acidic peaty soils which are not favorable for these species. The disappearance of the thick peat horizon can be the reason for some increase in species diversity found in Yamal (also in contrast to Canadian Arctic) as some more mineral-demanding species can more easily penetrate the surface.

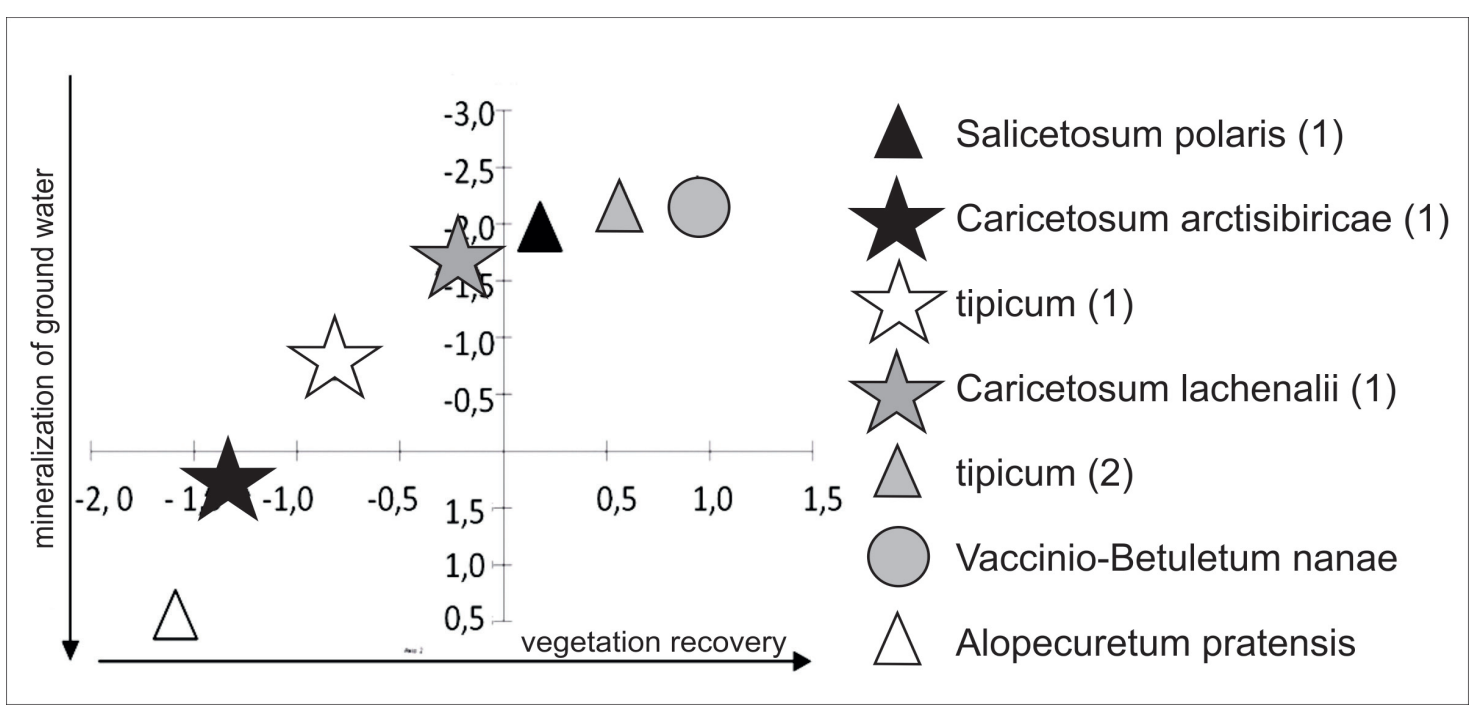

Fig. 7. Canonical correspondent analysis carried out on syntaxa distinguished in the central parts of shear surfaces of different ages showed correlation between groundwater salt content and vegetation changes. 
The total number of vascular plant species and green mosses slightly increased on all stages of recovery compared to the background. Studies in the neighboring Gydansky peninsula showed that herbaceous and willow-herbaceous communities found in ancient landslide cirques were among the most diverse (Khitun 1998), however only vascular plants were counted. However, this positive effect is diminished by the very slow rate of recovery.

Described patterns are typical for the central part of the Yamal Peninsula (about $260 \times 400 \mathrm{~km}$ in area) and also for neighboring Gydansky peninsula. It is likely that similar patterns can be observed in Chukotka plains but not in Yakutian maritime lowlands as they do not contain salts in the permafrost and have different vegetation complexes.

\section{Conclusions}

Natural cryogenic disturbances determine the structure and dynamics of vegetation on the marine plain slopes in Central Yamal. Communities are closely correlated with the age of landslides and their morphological elements. An important reason underpinning these successional dynamics is the decrease of salt content in groundwater, which changes from very high in the first years after detachment to slightly higher than background values on the more ancient surfaces. The recovery of bare shear surfaces takes dozens of years, for the first 10-15 years pioneer groupings dominated by grasses establish and they continue to develop for approximately the next 35-40 years, and afterwards are replaced by sedge-willow communities with relatively low ( $<50 \mathrm{~cm}$ high) Salix glauca and developed cover of mosses typical for tundra shrub communities. The first willow seedlings appear after 15-17 years and became abundant during the next ten years. In Central Yamal, the alliance Equiseto-Salicion glaucae indicates the presence of a landslide process, whereas its associations and sub-associations indicate age, the degree of mineral content of groundwater and morphological element of the landslide. Over the longer time frames, active layer detachment slides led to the formation of more productive derivative communities. In the severe climatic conditions of the Arctic, certain increases in mineral nutrition availability for plants due to the exposure and thawing of ancient marine salts can be considered as a compensating ecological factor, allowing the growth of higher willows normally not found in this subzone.

\section{ACKNOWLEDGEMENTS}

The study was funded by COLD-Yamal project via RFBR grant No. 13-05-91001-ANF-a to the Earth Cryosphere Institute SB RAS and by Komarov Botanical Institute RAS and its RFBR grants No. 10-04-0187-a and 13-04-01682-a. The comments of two anonymous reviewers helped considerably to improve the manuscript.

\section{REFERENCES}

ACIA 2005. Impacts of a warming Arctic: Arctic climate impact assessment scientific report. Cambrige University Press, Cambridge.

Aleksandrova VD 1969. Classification of vegetation. Principles of classification and classification systems of various phytosociological schools. Nauka, Leningrad (in Russian).

Andreev M, Kotlov Y \& Makarova I 1996. Checklist of lichens and lichenicolous fungi of the Russian Arctic. The Bryologist 99: 2, 137-169. http://dx.doi.org/10.2307/3244545.

Bhatt US, Walker DA, Raynolds MK, Comiso JC, Epstein HE, Jia GJ, Gens R, Pinzon JE, Tucker CJ, Tweedie GE \& Webber PJ 2010. Circumpolar Arctic tundra vegetation change is linked to sea-ice decline. Earth Interactions 14: 8, 1-20.

http://dx.doi.org/10.1175/2010EI315.1.

Braun-Blanquet J 1964. Pflanzensoziologie. Grundzuge der Vegetations-kunde. Springer-Verlag, Wien and New York.

Cannone N, Lewkowicz A \& Guglielmin M 2010. Vegetation colonization of permafrost-related landslides, Ellesmere Island, Canadian High Arctic. Journal of Geophysical Research 115: G4. http://dx.doi.org/10.1029/2010JG001384.

CAVM Team 2003. Circumpolar Arctic vegetation map. Conservation of Arctic flora and fauna map (CAFF) map no. 1. U.S. Fish and Wildlife Service, Anchorage, AK.

Czernyadjeva IV 1995. Materials to the moss flora from surroundings of Ngaranato lake (Central Yamal). Novosti Sistematiki Nizshih Rastenii 30, 134-137. (in Russian).

Edlund SA, Alt BT \& Young K 1989. Interaction of climate, vegetation and soil hydrology at Hot Weather Creek, Fosheim Peninsula, Ellesmere Island, Northwest Territories. In Geological survey of Canada, Current research 1989-D, 125-133. Natural Resourses Canada, Ottawa.

Ermokhina KA 2009. Phytoindication of exogenic processes in Central Yamal tundra. Candidate of science dissertation. Moscow University, Moscow (in Russian).

Forbes BC 1994. The importance of bryophytes in the classification of human-disturbed high arctic vegetation. Journal of Vegetation Science 5: 6, 877884. http://dx.doi.org/10.2307/3236200

Gauch HG Jr 1982. Multivariate analysis in community ecology. Cambridge University Press, Cambridge. 
Geertsema M \& Pojar J 2007. Influence of landslides on biophysical diversity - A perspective from British Columbia. Geomorphology 89: 1-2, 55-69. http://dx.doi.org/10.1016/j.geomorph.2006.07.019.

Gorlanova LA 2002. Methods of dendrochronological dating of landslide events. In Konishchev VN, Grechishchev SE, Leibman MO, Pavlov AV, Perlshtein GZ \& Khrustalev LN (eds). Extremal cryospheric phenomena: Fundamental and applied aspects, 148-149. Scientific Council on Earth Cryology RAS, Puschino.

Grime JP 1979. Plant strategies and vegetation processes. Wiley \& Sons, New York.

Harris C \& Lewkowicz AG 1993. Micromorphological investigations of active-layer detachment slides, Elesmere Island, Canadian Arctic. In Cheng G (ed). Proceedings of the 6th international conference on permafrost I, 233-237. South China University of Technology Press, Beijing.

Ignatov MS, Afonina OM \& Ignatova EA 2006. Check-list of mosses of East Europe and North Asia. Arctoa 15, 1-130.

Jorgenson MT 1997. Patterns and rates of and factors affecting natural recovery on land disturbed by oil development in Arctic Alaska. In Crawford RMM (ed). Disturbance and recovery in Arctic lands. An ecological perspective, 421-442. Kluwer Academic Publishers, Dordrecht.

Khitun OV 1997. Self-recovery after technogenic and natural disturbances in the central part of the Yamal Peninsula (West Siberian Arctic). In Crawford RMM (ed). Disturbance and recovery in Arctic lands. An ecological perspective, 531-552. Kluwer Academic Publishers, Dordrecht.

Khitun OV 1998. Comparative analysis of local and partial floras in two subzones of West Siberian Arctic (Gydansky and Tazovsky peninsulas). In Yurtsev BA (ed). Study of biodiversity with the methods of comparative floristics, 172-201. NIIH press, St.-Petersburg (in Russian).

Kovalskii VV \& Gololobov AD 1969. Methods of determination of microelements in organs and tissues of plants, animals and in soils. Kolos, Moscow (in Russian).

Korchagin AA, Lavrenko EM \& Ponyatovskaya VM (eds) 1964. Field geobotany V.3. (Polevaya geobotanika). Nauka, Moscow-Leningrad.

Kucherov IB \& Zagidullina AT 2001. Self-regeneration of plant communities: Examples, mechanisms, approaches to description. Zhurnal Obshchei Biologii 62: 5, 410-424. (in Russian).

Kumpula T, Pajunen A, Kaarlejärvi E, Forbes B \& Stammler F 2011. Land use and land cover change in Artic Russia: Ecological and social implications of industrial development. Global Environmental Change 21: 2, 550-562.

http://dx.doi.org/10.1016/j.gloenvcha.2010.12.010.

Kumpula T, Forbes B, Stammler F \& Meschtyb N 2012. Dynamics of a coupled system: Multi-resolution remote sensing in assessing social-ecological responses during 25 years of gas field development in Arctic Russia. Remote Sensing 4: 12, 1046-1068. http://dx.doi.org/10.3390/rs4041046.
Lantz TC, Kokelj SV, Gergel SE \& Henry GHR 2009. Relative impacts of disturbance and temperature: Persistent changes in microenvironment and vegetation in retrogressive thaw slumps. Global Change Bioogy 15: 7, 1664-1675.

http://dx.doi.org/10.1111/j.1365-2486.2009.01917.x.

Leibman MO 1995. Preliminary results of cryogenic landslides study on Yamal Peninsula, Russia. Permafrost and Periglacial Processes 6: 3, 259-264. DOI: $10.1002 / p p p .3430060307$.

Leibman MO 2004. Mechanisms of formation of cryogenic translation landslides and conditions for their indication by high willow shrubs on Central Yamal. Transactions of the Moscow Center of Russian Geographical Society. Biogeography 12, 89-94. RASHN, Moscow (in Russian).

Leibman MO \& Egorov IP 1996. Climatic and environmental controls of cryogenic landslides, Yamal, Russia. In Senneset K (ed). Landslides, 1941-1946. Balkema Publishers, Rotterdam.

Leibman MO \& Kizyakov Al 2007. Cryogenic landslides of the Yamal and Yugorsky Peninsulas. Earth Cryosphere Institute SB RAS, Moscow (in Russian).

Leibman MO, Rivkin FM \& Saveliev VS 1993. Hydrogeological aspects of cryogenic slides on the Yamal Peninsula. In Cheng G (ed). Permafrost. Proceedings of the 6th international conference 1, 380-382. South China University of Technology Press, Beijing. Leibman M, Khomutov A, Gubarkov A, Mullanurov D \& Dvornikov Y 2015. The research station "Vaskiny Dachi", Central Yamal, West Siberia, Russia - A review of 25 years of permafrost studies. Fennia 193: 1, 3-30.

Leibman MO, Khomutov AV, Orekhov PT, Khitun OV, Epstein H, Frost J \& Walker D 2012. Gradient of seasonal thaw depth along the Yamal transect. In Drozdov DS \& Romanovsky VE (eds). Proceedings of the 10th international conference on permafrost 2. Translations of Russian contributions, 237242. The Northern Publisher, Salekhard.

Lewkowicz AG 1990. Morphology, frequency and magnitude of active-layer detachment slides, Fosheim Peninsula, Ellesmere Island, N.W.T. In Burges MM, Harry DG \& Sego DC (eds). Proceedings of the 5th Canadian permafrost conference. Collection Nordicana 54, 111-118. Laval University, Quebec.

Lipovsky PS, Coates J, Lewkowicz AG \& Trochim E 2006. Active-layer detachments following the summer 2004 forest fires near Dawson City, Yukon. In Emond DS, Bradshaw GD, Lewis LL \& Weston LH (eds). Yukon Exploration and Geology 2005, 175-194. Yukon Geological Survey, Whitehorse, YT.

Mackay JR \& Mathews WH 1973. Geomorphology and Quaternary history of the Mackenzie River Valley near Fort Good Hope, N.W.T. Canadian Journal of Earth Sciences 10: 1, 26-41. http://dx.doi.org/10.1139/e73-003.

Matveeva NV 1989. Common trends in anthropogenic changes of tundra vegetation. Botanicheskii Zhurnal 74: 3, 426-431. 
Matveeva NV 2006. Vegetation of the southern part of the Bolshevik island (Severnaya Zemlya). Rastitelnost Rossii 8, 3-87.

Mirkin BM \& Naumova LG 1998. Vegetation science: History and present state of main concepts. Gilem, Ufa (in Russian).

Muc M, Freedman B \& Svoboda J 1989. Vascular plant communities of a polar oasis at Alexandra Fiord $\left(79^{\circ} \mathrm{N}\right)$, Ellesmere Island, Canada. Canadian Journal of Botany 67, 1126-1136.

Pizano C, Barón AF, Schuur EAG, Grummer KG \& Mack MC 2014. Effects of thermo-erosional disturbance on surface soil carbon and nitrogen dynamics in upland arctic tundra. Environmental Research Letters 9: 7, 075006. http://dx.doi.org/10.1088/1748-9326/9/7/075006.

Razumovskii LG 1981. Regularities of biocoenoses dynamics. Nauka, Moscow (in Russian).

Rebristaya OV, Khitun OV, Chernyadjeva IV \& Leibman MO 1995. Dynamics of vegetation on cryogenic landslides in Central Yamal. Botanicheskii Zhurnal 80: 4, 31-48. (in Russian).

Rebristaya OV \& Khitun OV 1998. Botanical-geographic specific of the Central Yamal's flora. Botanicheskii Zhurnal 83: 7, 37-52. (in Russian).

Sekretareva NA 1999. The vascular plants of the Russian Arctic and adjacent territories. Pent-Soft, Sofia and Moscow.

Sukachev VN 1934. What is phytocoenoses? Sovetskaya Botanika 5, 4-18. (in Russian).

Sumina Ol 2013. Formirovanie rastitelnosti na tekhnogennukh mestoobitaniyakh Krainego Severa Rossii (Formation of vegetation on technogenic habitats in Russian Far North). Info-Navigator, St.Petersburg (in Russian).

Tentyukov MP 1998. Geochemistry of the landscapes of Central Yamal. RAS Ural Branch Print, Ekaterinburg.

Tkachev YA \& Yudovich YE 1975. Statisticheskaya obrabotka geohimicheskih dannuh (Statistical treatment of geochemical data). Nauka, Leningrad (in Russian).

Ukraintseva NG 1997. Willow tundra in Yamal as the indicator of salinity of superficial sediments. In Results of basic research on the Earth cryosphere in Arctic and Subarctic, 182-187. Nauka, Novosibirsk.

Ukraintseva NG 1998. Specific of distribution of shrub tundras on Yamal. In Transactions of Moscow Centre of Russian Geographical Society, ser. Biogeography 7, 46-53. RASHN, Moscow (in Russian).

Ukraintseva NG 2008. Vegetation response to landslide spreading and climate change in the West Siberian tundra. In Kane DL \& Hinkel KM (eds). Proceedings of the 9th international conference on permafrost 2, 1792-1798. University of Alaska, Fairbanks.

Ukraintseva NG, Leibman MO \& Streletskaya ID 2000. Peculiarities of landslide process in saline frozen deposits of Central Yamal, Russia. In Bromhead E (ed). Landslides in research, theory and practice: Proceedings of the 8th international symposium on landslides 3, 1495-1500. Thomas Telford, London.
Ukraintseva NG, Streletskaya I, Ermokhina KA \& Yermakov SY 2003. Geochemical properties of plantsoil-permafrost system at landslide slopes, Yamal, Russia. In Phillips M, Springman SM, Arenson LU (eds). Permafrost. Proceedings of the 8th international conference 2, 1149-1154. A.A. Balkema Publishers, Lisse.

Viktorov SV \& Remezova GL 1988. Indicatory geobotany. Moscow University Print, Moscow (in Russian).

Vinogradov BV 1964. Vegetation indicators and their use in study of nature resources. Higher school, Moscow (in Russian).

Walker DA 2013. Overview of the Arctic vegetation archive workshop. In Walker DA, Breen AL, Raynolds MK \& Walker MD (eds). Arctic vegetation archive workshop, 14-16 April, Krakow, Poland. CAFF proceedings report no. 10, 6-11. Akureyri, Iceland.

Walker LR \& del Moral R 2003. Primary succession and ecosystem rehabilitation. Cambridge University Press, Cambridge.

Walker DA \& Walker MD 1991. History and pattern of disturbance in Alaskan Arctic terrestrial ecosystems: A hierarchical approach to analyzing landscape change. Journal of Applied Ecology 28: 1, 244-276. http://dx.doi.org/10.2307/2404128.

Walker DA, Cate D, Brown J \& Racine C 1987. Disturbance and recovery of arctic Alaskan tundra terrain. A review of recent investigations. Report no. 87-11. US Army Cold Regions Research and Engineering Laboratory, Hanover, $\mathrm{NH}$.

Walker DA, Epstein HE, Raynolds MK, Kuss P, Kopecky MA, Frost GV, Daniëls FJA, Leibman MO, Moskalenko NG, Matyshak GV, Khitun OV, Khomutov AV, Forbes BC, Bhatt US, Kade AN, Vonlanthen CM \& Tichý L 2012. Environment, vegetation and greenness (NDVI) along the North America and Eurasia Arctic transects. Environmental Research Letters 7: 1, 015504. http://dx.doi.org/10.1088/1748-9326/7/1/015504.

Walker DA, Leibman MO, Epstein HE, Forbes BC, Bhatt US, Raynolds MK, Comiso JC, Gubarkov AA, Khomutov AV, Jia GJ, Kaarlejärvi E, Kaplan JO, Kumpula T, Kuss P, Matyshak G, Moskalenko NG, Orekhov P, Romanovsky VE, Ukraintseva NG \& Yu Q 2009. Spatial and temporal patterns of greenness on the Yamal Peninsula, Russia: Interactions of ecological and social factors affecting the Arctic normalized difference vegetation index. Environmental Research Letters 4: 4, 045004. http://dx.doi.org/10.1088/1748-9326/4/4/045004.

Weber HE, Moravec J \& Theurillat J-P 2000. International code of phytosociological nomenclature. Journal of Vegetation Science 5: 5, 765-774. http://dx.doi.org/10.2307/3236580.

Yermokhina KA \& Myalo EG 2012. Phytoindicators of landslide disturbances in the Central Yamal. In Drozdov DS \& Romanovsky VE (eds). Proceedings of the 10th international conference on permafrost 2 .Translations of Russian contributions, 531-536. The Northern Publisher, Salekhard. 

Yershov ED 1998. General geocryology (stud-
ies in Polar Research). Carleton University, Ottawa.

Yurtsev BA 1994. Floristic division of the Arctic. Journal of Vegetation Science 5: 6, 765-774. http://dx.doi.org/10.2307/3236191. 